\title{
Research Square \\ Biological elimination of a high concentration of hydrogen sulfide from landfill biogas
}

Rania Ibrahim

Universite de Sherbrooke

Abdessamad El Hassni

Universite de Sherbrooke

Shahram Navaee-Ardeh

Universite de Sherbrooke

Hubert Cabana ( $\nabla$ Hubert.Cabana@USherbrooke.ca )

Universite de Sherbrooke https://orcid.org/0000-0003-3417-6816

\section{Research Article}

Keywords: Biogas, Hydrogen sulfide, Biotrickling filter, Landfill biogas, $\mathrm{H} 2 \mathrm{~S}$ removal

Posted Date: April 6th, 2021

DOI: https://doi.org/10.21203/rs.3.rs-312009/v1

License: (c) (1) This work is licensed under a Creative Commons Attribution 4.0 International License. Read Full License

Version of Record: A version of this preprint was published at Environmental Science and Pollution Research on July 31st, 2021. See the published version at https://doi.org/10.1007/s11356-021-15525-7. 


\section{Biological elimination of a high concentration of hydrogen sulfide from landfill biogas}

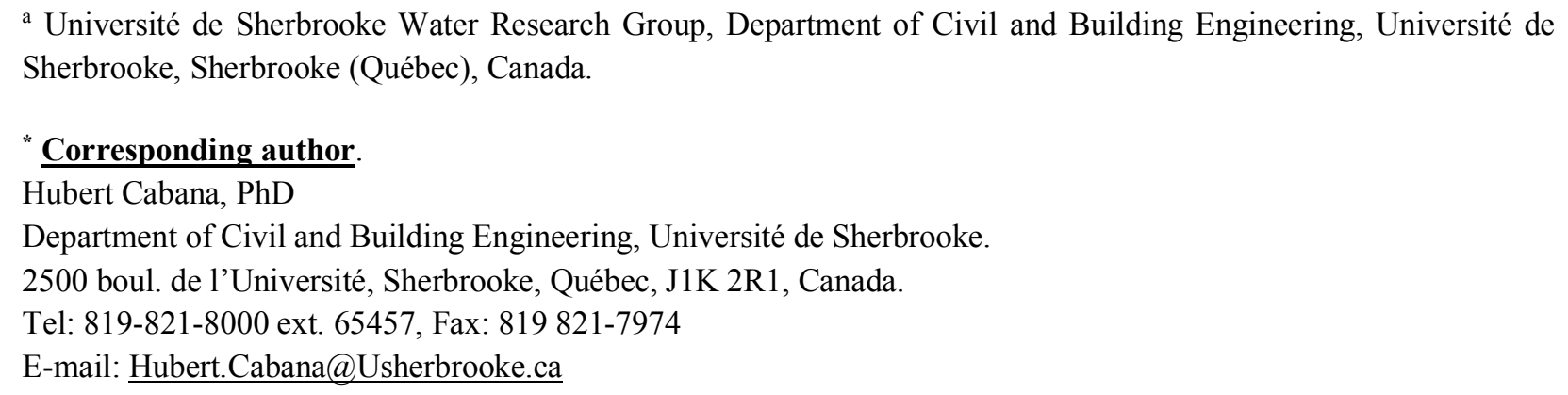


ABSTRACT

15 Hydrogen sulfide $\left(\mathrm{H}_{2} \mathrm{~S}\right)$ is one of the main contaminants found in biogas which is one of the end products of the 16 anaerobic biodegradation of proteins and other sulfur-containing compounds in solid waste. The presence of $\mathrm{H}_{2} \mathrm{~S}$ is 17 one of the factors limiting the valorization of biogas. To valorize biogas, $\mathrm{H}_{2} \mathrm{~S}$ and other contaminants must be removed. 18 This study evaluated the performance of a pilot-scale biotrickling filter system on $\mathrm{H}_{2} \mathrm{~S}$ removal from landfill biogas. 19 The biotrickling filter system, which was packed with stainless-steel pall rings and inoculated with an $\mathrm{H}_{2} \mathrm{~S}$-oxidizing consortium, was designed to process 1 to 10 SCFM of biogas and used to determine the removal efficiency of a high

21 concentration of hydrogen sulfide from landfill biogas. The biofiltration system consisted of two biotrickling filters

22 connected in series. Results indicate that the biofiltration system reduced $\mathrm{H}_{2} \mathrm{~S}$ concentration by $94 \%$ to $97 \%$ without 23 reduction of the methane concentration in the outlet biogas. The inlet concentration of hydrogen sulfide, supplied to 24 the two-phase bioreactor, was in the range of 900 to 1500 ppmv. The hydraulic retention times (HRT) of the two 25 biotrickling filters were 3.9 and 0.9 min, respectively. Approximately $50 \mathrm{ppmv}$ of $\mathrm{H}_{2} \mathrm{~S}$ gas was detected in the outlet 26 gas. The maximum elimination capacity of the biotrickling filter system was found to be $272 \mathrm{~g} \mathrm{H}_{2} \mathrm{~S} \cdot \mathrm{m}^{-3} \cdot \mathrm{h}^{-1}$. During 27 the biological process, the performance of biotrickling filter was not affected when the $\mathrm{pH}$ of the recirculated liquid decreased to 2-3. The overall performance of the biotrickling filter system was described using a modified Michaelis-

29 Menten equation, and the $\mathrm{K}_{\mathrm{s}}$ and $\mathrm{V}_{\mathrm{m}}$ values for the biosystem were $34.7 \mathrm{ppmv}$ and $200 \mathrm{mg} \mathrm{H}_{2} \mathrm{~S} / \mathrm{L} \cdot \mathrm{h}^{-1}$, respectively.

30 Keywords: Biogas; Hydrogen sulfide; Biotrickling filter; Landfill biogas; $\mathrm{H}_{2} \mathrm{~S}$ removal. 
33 Biogas is one of the end products of the anaerobic digestion process. This process involves a series of metabolic stages

34 (hydrolysis, acidogenesis, acetogenesis, and methanogenesis), in which a consortium of microorganisms degrades the organic substances in the absence of oxygen. Landfill biogas is a renewable energy consisting mainly of methane (45$55 \% \mathrm{v} / \mathrm{v})$, carbon dioxide $(30-40 \% \mathrm{v} / \mathrm{v})$, and some trace components such as volatile organic compounds, hydrogen sulfide $\left(\mathrm{H}_{2} \mathrm{~S}\right)$ and other sulfur-containing compounds (Rasi et al. 2007). $\mathrm{H}_{2} \mathrm{~S}$ should be removed from the gaseous stream to be used as an energy source (biomethane) for generating electricity and heat. $\mathrm{H}_{2} \mathrm{~S}$ concentration in landfill biogas usually ranges from 1000 to 2000 ppmv (Lastella et al. 2002). It is a toxic, flammable, and colorless gas with a characteristic odor of rotten eggs (Roth 1993). The main problems that occur as a result of high $\mathrm{H}_{2} \mathrm{~S}$ concentrations in biogas are (i) damages engines and other equipment due to its corrosive action, and (ii) $\mathrm{H}_{2} \mathrm{~S}$ combustion, which produces sulfur oxides $\left(\mathrm{SO}_{\mathrm{x}}\right)$ and causes emissions of increasing environmental concern (Dumont 2015). As a result, $\mathrm{H}_{2} \mathrm{~S}$ in biogas must be removed to avoid treatment facility corrosion, unnecessary production of by-products, and possible public exposure and complaints (Namgung et al. 2012). $\mathrm{H}_{2} \mathrm{~S}$ gas elimination processes include either physical or chemical oxidation treatments. These methods are rapid and effective but require the addition of chemicals which are unhealthy, costly and generate secondary wastes. To get control of these limitations, biological oxidation treatment process can be an alternative to a physico-chemical system due to its low energy consumption and cost, high efficiency, and environmental acceptability (Kennes et al. 2009). Biofiltration of $\mathrm{H}_{2} \mathrm{~S}$ has been extensively studied ((Dumont 2015); (Abatzoglou and Boivin 2009)) yet there is still a gap in the research that has been carried out regarding the treatment of landfill biogas and this is what this research

51 investigates.

52 The biofiltration technique is the ability of microorganisms to degrade organic matter for their own metabolism. In 53 biofilm, the contaminant air is transferred from a gas phase to a liquid phase (Eq. 1) where microbial attack occurs. 54 For the biodegradation of $\mathrm{H}_{2} \mathrm{~S}$, sulfur-oxidizing bacteria (SOB) are used to oxidize $\mathrm{H}_{2} \mathrm{~S}$ to sulfur product (sulfate and 55 sulfur). The following overall biological reactions (Oyarzún et al. 2003) can be expressed by Eq. 2 to 4 :

$56 \quad \mathrm{H}_{2} \mathrm{~S} \leftrightarrow \mathrm{H}^{+}+$HS- (non-biological)

$57 \quad \mathrm{HS}+0.5 \mathrm{O}_{2} \rightarrow \mathrm{S}^{0}+\mathrm{OH}$ (biological)

$58 \mathrm{~S}^{\circ}+1.5 \mathrm{O}_{2}+\mathrm{H}_{2} \mathrm{O} \rightarrow \mathrm{SO}^{2}+2 \mathrm{H}^{+}($biological $)$ 
During biological oxidation of $\mathrm{H}_{2} \mathrm{~S}$, the $\mathrm{H}_{2} \mathrm{~S}$ first dissolves, releasing a proton to the caustic liquid phase (Eq. 1). The biological conversion of $\mathrm{H}_{2} \mathrm{~S}$ to elemental sulfur $\left(\mathrm{S}^{0}\right)$ or sulfate $\left(\mathrm{SO}_{4}{ }^{2-}\right)$ is directly related to the availability of oxygen, according to Eqs. (2) and (3). In the case of low oxygen concentration, the oxidation proceeds only to $\mathrm{S}^{0}$. Consequently, due to the accumulation of $\mathrm{S}^{0}$ over time, the biotrickfilter bed yellows and causes clogging. Generally, sulfide is oxidized to sulfate $\left(\mathrm{SO}_{4}{ }^{2-}\right.$ ) (Eq. 4) by a mixed population of sulfur-oxidizing bacteria (SOB) when enough oxygen is provided; the overall reaction (Eq.4) occurs with no production of elemental sulfur as an intermediate. However, since oxygen is plentiful in air, most of the $\mathrm{H}_{2} \mathrm{~S}$ is converted into sulfate, causing media acidification. In this way, accurate control of the oxygen level is a key parameter for controlling reactor performance (approximately $5 \%$ vol depending on the $\mathrm{H}_{2} \mathrm{~S}$ inlet concentration) (Schomaker et al. 2000). For safety reasons and, it is necessary to control the concentration of oxygen because the lower and upper explosive limits for methane in biogas are $9.2 \mathrm{~mol} \%$ and 23.2 mol\%, respectively (Schroeder et al. 2014).

The type of packing material can control biotrickling filter performances. Different types of packing material such as organic, inorganic, and synthetic have been used. The organic materials include soil, peat, bamboo charcoal, pine bark, and ceramsite, which have been widely used because of their porosity and low costs and their capacity to adsorb contaminants (Chen et al. 2014; Jaber et al. 2014). Inorganic materials used in biofilters include, among others, lava rocks (Soreanu et al. 2009) and expanded schist (ben Jaber et al. 2016). The use of inorganic materials can be favorable because of their availability and excellent physical and mechanical properties which can limit pressure drops even during a long operating period ((Dumont et al. 2012). In general, packing materials must be inoculated with various microbial communities contained in activated sludge, which are responsible for $\mathrm{H}_{2} \mathrm{~S}$ removal in the biofilter. In addition, nutrient equilibrium plays an important role in microbial growth. Biofilters are usually irrigated by a nutrient solution to provide necessary nutrients for microbial growth and to maintain the bed moisture, in addition to the elimination of the by-products produced during the biological oxidation reaction.

Biofiltration has been widely used to remove $\mathrm{H}_{2} \mathrm{~S}$ from biogas (Dumont 2015). However, previous studies have mainly focused on the biofiltration of $\mathrm{H}_{2} \mathrm{~S}$ at concentrations of less than 200 ppmv (Jin et al. 2005; Tang et al. 2009). Only a few studies on biofiltration have been carried out at high $\mathrm{H}_{2} \mathrm{~S}$ concentrations, i.e., above 4000 ppmv in synthetic biogas (Fortuny et al. 2008; Rattanapan et al. 2009; Montebello et al. 2013), but even fewer have been done using real biogas with high $\mathrm{H}_{2} \mathrm{~S}$ as the inlet gas in a lab-scale reactor (Tomàs et al. 2009; Chaiprapat et al. 2011; Rodriguez et al. 2014). As a result of the production of sulfuric acid generated by the oxidation of $\mathrm{H}_{2} \mathrm{~S}$, the biotrickling filter media 
becomes substantially acidified. When the biofiltration system is operated with high $\mathrm{H}_{2} \mathrm{~S}$ inlet load, the $\mathrm{pH}$ decreases. This acidification reduces the solubilization of $\mathrm{H}_{2} \mathrm{~S}$ in water (Eq. 1). On the other hand, SOB is well adapted to low pH conditions (Robertson and Kuenen 2006).

The purpose of this study was to evaluate the performance of a pilot-scale biotrickling filter system for removing $\mathrm{H}_{2} \mathrm{~S}$ from landfill biogas (1000-2000 ppmv), while maintaining the energy quality of the purified biogas, using an immobilized sulfur-oxidizing bacteria consortium. Thiosulfate and bicarbonate were used to immobilize sulfur oxidation activity and microbial growth in a 1-L lab-scale reactor and were then applied into the biotrickling filter. The immobilization and operation processes of $\mathrm{H}_{2} \mathrm{~S}$ removal from the biogas by an $\mathrm{SOB}$ were evaluated to derive the optimum process. Moreover, the kinetic analysis of biological $\mathrm{H}_{2} \mathrm{~S}$ removal using immobilized cells was also investigated.

\section{MATERIALS AND METHODS}

\section{Microorganisms and culture medium}

Activated sludge from a local municipal wastewater treatment plant (Magog, Quebec, Canada) with a suspended material concentration of $3.5 \mathrm{~g} / \mathrm{L}$ was used for the initial inoculation of the reactor. The latter was used to develop an $\mathrm{H}_{2} \mathrm{~S}$-oxidizing bacteria consortium, which consists of chemolithotroph bacteria known for their ability to grow in sulfur-containing media (Schedel et al. 1975). The thiosulfate mineral medium (TMM) contained the following: 15g/L $\mathrm{Na}_{2} \mathrm{~S}_{2} \mathrm{O}_{3} .5 \mathrm{H}_{2} \mathrm{O}, 4 \mathrm{~g} / \mathrm{L} \mathrm{K} \mathrm{HPO}_{4}, 4 \mathrm{~g} / \mathrm{L} \mathrm{KH}_{2} \mathrm{PO}_{4}, 0.8 \mathrm{~g} / \mathrm{L} \mathrm{MgSO}_{4} \cdot \mathrm{H}_{2} \mathrm{O}, 0.4 \mathrm{~g} / \mathrm{L} \mathrm{NH} \mathrm{H}_{4} \mathrm{Cl}, 22 \mathrm{~g} / \mathrm{L} \mathrm{NaHCO}, 50 \mathrm{~g} / \mathrm{L}$ EDTA, $22 \mathrm{~g} / \mathrm{L} \quad \mathrm{ZnSO}_{4} .7 \mathrm{H}_{2} \mathrm{O}, 5.54 \mathrm{~g} / \mathrm{L} \quad \mathrm{CaCl}_{2}, 5.06 \mathrm{~g} / \mathrm{L} \quad \mathrm{MnCl}_{2} .4 \mathrm{H}_{2} \mathrm{O}, 4.99 \mathrm{~g} / \mathrm{L} \quad \mathrm{FeSO}_{4} .7 \mathrm{H}_{2} \mathrm{O}, 1.1 \mathrm{~g} / \mathrm{L}\left(\mathrm{NH}_{4}\right) 6 \mathrm{MO}_{7} \mathrm{O}_{24} \cdot \mathrm{H}_{2} \mathrm{O}$,

$1.57 \mathrm{~g} / \mathrm{L} \mathrm{CuSO} 4.5 \mathrm{H}_{2} \mathrm{O}, 1.61 \mathrm{~g} / \mathrm{L} \mathrm{CoCl} 2.6 \mathrm{H}_{2} \mathrm{O}$ and $2 \mathrm{~g} / \mathrm{L}$ yeast extract. During the acclimation process, the inorganic carbon source used was sodium bicarbonate, while the source of sulfur used was sodium thiosulfate.

The TMM medium was used as a recirculating liquid in the biotrickling filter system for the immobilization process, as well as for maintaining microorganisms. By adding $1 \mathrm{~N} \mathrm{NaOH}$ or $1 \mathrm{~N} \mathrm{HCl}$, the final $\mathrm{pH}$ of this medium was adjusted to 7 .

\section{Acclimation and enrichment procedure}

In 1-liter Erlenmeyer flasks, containing $500 \mathrm{~mL}$ of culture medium, $500 \mathrm{~mL}$ of activated sludge was added. The Erlenmeyer flasks were placed on a magnetic stirrer at room temperature. Air was continuously supplied with a stainless-steel diffuser to ensure aerobic conditions. The agitation was set at $100 \mathrm{rpm}$ to avoid leading to shear forces of the biomass flocs. Bacterial growth (optical density), $\mathrm{pH}$ and dissolved oxygen were monitored daily. To guarantee 
aerobic conditions, the $\mathrm{O}_{2}$ concentration must be maintained between at least $2 \mathrm{mg} / \mathrm{L}$ and $4 \mathrm{mg} / \mathrm{L}$ (Wilen and Balmer 1999). During a decrease in the biomass concentration, as a result of a depletion of the nutrients, the culture medium was renewed at a rate of $30 \%$ by volume.

\section{Inoculation of the lab-scale bioreactor}

120 A volume of $500 \mathrm{~mL}$ of three-day acclimated bacterial suspension with an optical density equivalent to 4.5 (absorbance 121 at $600 \mathrm{~nm}$ ) was transferred to the laboratory-scale bioreactor (diameter $=10 \mathrm{~cm} \&$ height $=17 \mathrm{~cm}$ ); see Figure 1 . For 122 one month, the reactor, which was made of glass with a total volume of $1000 \mathrm{~mL}$, was continuously supplied with a 123 synthetic biogas composed of $\mathrm{H}_{2} \mathrm{~S}(0.07$ to $0.2 \% \mathrm{v} / \mathrm{v}), \mathrm{CO}_{2}(20 \% \mathrm{v} / \mathrm{v})$ and air $(100 \%$ balance $)$. The experimental 124 conditions for these laboratory tests are summarized in Table 1. During the lab-scale tests, the initial $\mathrm{H}_{2} \mathrm{~S}$ concentration 125 was initially $730 \mathrm{ppmv}$; then it was gradually increased to 1000 and $2000 \mathrm{ppmv}$ at 3-day intervals. One part (300 $\mathrm{mL})$ 126 of the culture medium was renewed every 72 hours when there was a decrease in the rate of biomass growth (optical 127 density) in the reactor.

\section{Pilot-scale bioreactor}

\section{Packing materials}

Stainless-steel pall rings (DN16) (Masaito Metal Company, Ltd., Hengshui City, China) were used as a support for the microbial population in this study. The pall rings are cylindrical in appearance, and their height is the same as their diameter $(16 \mathrm{~mm})$, as shown in Fig.2. The packing material had a high porosity of $95 \%$. The physical characteristics of the stainless-steel pall rings are summarized in Table 2.

\section{Pilot-scale set-up and operation conditions}

135 The pilot-scale system for $\mathrm{H}_{2} \mathrm{~S}$ biofiltration is shown in Fig.3. It consisted of two biotrickling filters connected in series (BTF1 and BTF2) made of PVC. The first biotrickling filter (BTF1) has an inner diameter of $0.4 \mathrm{~m}$ and a height

137 of $1.5 \mathrm{~m}$. While the second biotrickling filter (BTF2) has an inner diameter of $0.2 \mathrm{~m}$ and a height of $1.3 \mathrm{~m}$. The two 138 columns were filled with the same packing material (stainless-steel pall rings DN16). The effective volume of the BTF1 was 110 liters, which corresponds to $0.9 \mathrm{~m}$ in height of DN16, while the effective volume of the BTF2 was 25

140 liters ( $0.8 \mathrm{~m}$ height). The real inlet biogas consisted of $52 \% \mathrm{v} / \mathrm{v}$ of methane, $39 \% \mathrm{v} / \mathrm{v}$ of $\mathrm{CO}_{2}, 11 \% \mathrm{v} / \mathrm{v}$ of $\mathrm{CO}, 1.2 \%$ 141 of $\mathrm{O}_{2}$, and 1000-2000 ppmv of $\mathrm{H}_{2} \mathrm{~S}$. The flow rate was controlled via a flow meter and regulator on the biogas pipe. 
of the BTF1 and BTF2 at a constant flow rate of $1 \operatorname{SCFM}(28.3 \mathrm{~L} / \mathrm{min})$ and $0.9 \operatorname{SCFM}(27.7 \mathrm{~L} / \mathrm{min})$, respectively. Part

144

145

146

147

of the pre-treated biogas was exhausted after BTF1. Throughout the experimental period, the biogas compositions were measured periodically, and the percolate at the bottom of each biotrickling filter was evaluated to determine its $\mathrm{pH}$, concentrations of sulfate and COD. In this experiment, the two biotrickling filters were first inoculated with the thiosulfate mineral medium (TMM) from the lab-scale reactor for 3 days. The medium prepared for the cultivation of the bacteria contained $5 \mathrm{~g} / \mathrm{L} \mathrm{Na}_{2} \mathrm{~S}_{2} \mathrm{O}_{2} .5 \mathrm{H}_{2} \mathrm{O}, 1.5 \mathrm{~g} / \mathrm{L} \mathrm{KH}_{2} \mathrm{PO}_{4}, 1.5 \mathrm{~g} / \mathrm{L} \mathrm{K}_{2} \mathrm{HPO}_{4}, 0.4 \mathrm{~g} / \mathrm{L} \mathrm{NH}_{4} \mathrm{Cl}, 0.2 \mathrm{~g} / \mathrm{L} \mathrm{MgCl} 2.6 \mathrm{H}_{2} \mathrm{O}$, and $0.01 \mathrm{~g} / \mathrm{L} \mathrm{FeSO}_{4} .7 \mathrm{H}_{2} \mathrm{O}$. This medium was added into Reservoir 1 and fed into the reactor via a peristaltic pump. After the immobilization process, $\mathrm{Na}_{2} \mathrm{~S}_{2} \mathrm{O}_{3} .5 \mathrm{H}_{2} \mathrm{O}$ was removed from the liquid medium in the recirculation tank.

When the reactor system was operating, due to an increase of sulfate concentration in the liquid medium, which is induced by the biological oxidation of $\mathrm{H}_{2} \mathrm{~S}$, a $30 \%$ volume of fresh medium was renewed every 7 days to maintain the level of $\mathrm{SO}^{-2}{ }_{4}$ buildup below $40 \mathrm{~g} / \mathrm{L}$. This nutrition solution was sprayed downward for the downflow mode of operation to maintain the bed moisture and provide necessary nutrients for microbial growth, in addition to the elimination of the by-products produced during the biological oxidation reaction. The nutrition solution flow rate was constant at $3.8 \mathrm{1} / \mathrm{min}$, discharged from the bottom, and recycled. The operational conditions of BTF1 and BTF2 are summarized in Table 3.

\section{Kinetic analysis}

The removal rate of hydrogen sulfate was calculated using the equation below (Eq.4), which was derived from the Michaelis-Menten equation (Ma et al. 2006; Hirai et al. 1990; Chen et al. 2014; Chung et al. 2001)

$\frac{1}{R}=\frac{K_{S}}{V_{m}} \times \frac{1}{C_{l n}}+\frac{1}{V_{m}}$

Where $R$ is the apparent removal rate in $m g \mathrm{H}_{2} \mathrm{~S} / \mathrm{L} / \mathrm{h}, K_{s}$ is the apparent half-saturation constant in ppmv, $V_{m}$ is the maximum apparent removal rate in $\mathrm{mg} \mathrm{H}_{2} \mathrm{~S} / \mathrm{L} / \mathrm{h}$, and $C_{\text {ln }}=\left(C_{\text {in }}-C_{\text {out }}\right) / \ln \left(C_{\text {in }} / C_{\text {out }}\right)$, is the logarithmic mean of $\mathrm{H}_{2} \mathrm{~S}$ concentration in the biotrickling filter ; $C_{\text {in }}$ (ppmv) is the inlet concentration of $\mathrm{H}_{2} \mathrm{~S}$ in the biotrickling filter; $C_{\text {out }}$ (ppmv) is the outlet concentration of $\mathrm{H}_{2} \mathrm{~S}$ in the biotrickling filter. From the linear relationship between $1 / C_{l n}$ and $1 / R$ (Lineweaver-Barker method), the kinetic constants $V_{m}$ and $K_{s}$ of the biological degradation of hydrogen sulfate were calculated from the intercept and slope, respectively. 


\section{Analytical methods}

170 Inlet and outlet concentrations of $\mathrm{H}_{2} \mathrm{~S}$ gas were continuously measured by using a colorimetric gas detection tube 171 (Gastec corporation, Japan). The $\mathrm{H}_{2} \mathrm{~S}$ tube detection ranges were 2000 and 1-200 ppm for inlet and outlet $\mathrm{H}_{2} \mathrm{~S}$ gas 172 concentrations, respectively. Methane, carbon dioxide, and oxygen were periodically measured with a portable gas 173 analyzer (Landtec GEM5000) (QED Environmental Systems, Inc., United States). The spectrophotometric method 174 (Hach-DR-2000) was used to determine the sulfate concentrations as described by APHA (1992). Sulfate samples 175 were taken periodically from Reservoir 1 and Reservoir 2 (nutrition tanks). The $\mathrm{pH}$ of the nutrition solution was 176 measured using a calibrated digital pH-meter (Mettler Toledo, Canada). The growth of the microorganisms was 177 monitored by measuring the optical density of the growth medium at $600 \mathrm{~nm}$ with a spectrophotometer SpectraMax 178 Plus 384 (Molecular Devices Corp., Sunnyvale, California, United States). After adequate dilution, depending on the 179 turbidity of the suspension, the absorbance of the sample taken was measured against a blank, which consisted of 180 distilled water. The final absorbance was the absorbance read for the diluted sample multiplied by the dilution factor.

181 The chemical oxygen demand (COD) of the nutrient solution was determined by using the Hach-DR-2000 analyzer 182 according to the standard method (Jirka and Carter 1975). The COD values were measured by using AccuSPEC 183 reagent tubes (1500 ppm) (SCP SCIENCE Company, Québec, Canada).

184 The ICP-MS methodology was used for heavy metal quantification in wastewater (CEAEQ, 2012).

185 The removal efficiency (RE), the elimination capacity (EC), and the loading rate (LR) of the biotrickling filters were 186 calculated as follows:

$187 R E(\%)=\frac{C_{\text {in }}-C_{\text {out }}}{C_{\text {in }}} \times 100$

$E C\left(g m^{-3} h^{-1}\right)=\frac{\mathrm{Q}}{\mathrm{V}}\left(C_{\text {in }}-C_{\text {out }}\right)$

$L R\left(g m^{-3} h^{-1}\right)=\frac{\mathrm{Q}}{\mathrm{V}} C_{\text {in }}$

Where $C_{\text {in }}$ and $C_{\text {out }}$ are the inlet and outlet gas concentrations $\left(\mathrm{g} \mathrm{m}^{-3}\right)$ respectively, Q is the gas flow rate $\left(\mathrm{m}^{3} \mathrm{~h}^{-1}\right)$ and $\mathrm{V}$ is the bed volume of packing material $\left(\mathrm{m}^{3}\right)$. 

Immobilization and acclimatization of the consortium

The thiosulfate mineral medium (TMM) containing SOB was loaded into the lab-scale reactor with sodium bicarbonates being the sole carbon source and thiosulfate being the sole energy source supporting SOB growth. Fig. 4

197 shows the SOB growth and sulfate production when the $\mathrm{pH}$ of the medium was adjusted daily to 7 without the replacement of fresh medium. The $\mathrm{pH}$ was in the range of $6-7$. The acclimation process was performed for 45 hours. This process reached a 4.5 optical density after 20 hours corresponding to a sulfate concentration of $2 \mathrm{~g} / \mathrm{L}$. After a 20hour operating period, the optical density decreased to 4 as the sulfate concentration increased to $10 \mathrm{~g} / \mathrm{L}$. The concentration of the accumulated sulfate in the medium was $6 \mathrm{~g} / \mathrm{L}$. This value posed a toxic effect on the SOB growth as indicated by the decreasing optical density and would subsequently affect the oxidation activity of thiosulfate in the lab-scale system. To avoid the accumulation of sulfate in the medium, a 30\% volume of the medium was renewed when the growth rate of the biomass decreased. In the biotrickling filter system, SOB was immobilized successfully on the packing bed by recirculating the liquid which was inoculated from the lab-scale reactor. The recirculation liquid flow rate was $3.8 \mathrm{~L} / \mathrm{min}$. Throughout the immobilization process, it was observed that the elemental sulfur was accumulating on the packing media (result not shown). After 3 days, real biogas gradually flowed into the reactor system until 1 SCFM.

\section{Removal of hydrogen sulfide in the lab-scale reactor}

210 The experiment was performed at the lab-scale level for 60 days using an average inlet $\mathrm{H}_{2} \mathrm{~S}$ concentration of 2400

211 ppmv. In the first phase (40 days of operation), the $\mathrm{H}_{2} \mathrm{~S}$ was generally removed by $38 \%$ to $80 \%$ for corresponding 212 outlet concentrations of 1500 to 500 ppmv, respectively.

213 In the second phase (between Days 40 and 60), the $\mathrm{H}_{2} \mathrm{~S}$ removal efficiencies were always higher than $99 \%$ and the 214 effluent concentrations were below the detection limit of $2 \mathrm{ppmv}$, as shown in Fig.5. The maximum EC was 215 determined as $50 \mathrm{~g} \mathrm{H}_{2} \mathrm{~S} \cdot \mathrm{m}^{-3} \mathrm{~h}^{-1}$ at the loading rate of $330 \mathrm{~g} \mathrm{H}_{2} \mathrm{~S} \cdot \mathrm{m}^{-3} \mathrm{~h}^{-1}$. The results showed that the high removal 216 efficiency was due to the consortia adaptation from the first phase and subsequently the increasing bacterial growth 217 in the second phase. Moreover, the removal efficiency of $\mathrm{H}_{2} \mathrm{~S}$ increased with increasing operating times. This result 218 was consistent with other researchers on $\mathrm{H}_{2} \mathrm{~S}$ removal from biogas in a lab-scale reactor (Table 4). 
Figure 6 shows the evolution of sulfate ions, biomass, and $\mathrm{pH}$ in the reactor. These figures show a good correlation with the whole $\mathrm{H}_{2} \mathrm{~S}$ removal process. However, the higher the biomass concentration, the more sulfate ions were produced, which acidified the medium. This is consistent with bacterial metabolism for hydrogen sulfide.

\section{Biodegradation of $\mathrm{H}_{2} \mathrm{~S}$ in the pilot-scale bioreactor}

223 The $\mathrm{H}_{2} \mathrm{~S}$ removal from landfill biogas was tested by using two biotrickling filters connected in series packed with 224 stainless-steel pall rings. The $\mathrm{H}_{2} \mathrm{~S}$ inlet concentrations were between 900 and 1500 ppmv. Fig. 7 shows the $\mathrm{H}_{2} \mathrm{~S}$ removal 225 efficiencies in the two biotrickling filters packed with stainless-steel pall rings during 90 days of operation.

226 During the operation of BTF1, a 94\% removal efficiency average for 900-1500 ppmv of $\mathrm{H}_{2} \mathrm{~S}$ was achieved, and 227 approximately $50 \mathrm{ppm}$ of $\mathrm{H}_{2} \mathrm{~S}$ gas was detected in the outlet of BTF1. BTF1 was found to be about $25 \%$ more effective 228 in removing $\mathrm{H}_{2} \mathrm{~S}$ than BTF2 due to the different kinetics in BTF2 resulting from the lower inlet concentration of $\mathrm{H}_{2} \mathrm{~S}$. 229 Whereas, after adding BFT2 to the system, the removal efficiency of the whole system increased to 98\%.

230 Furthermore, the maximum EC in BTF2 $\left(81 \mathrm{~g} \mathrm{H}_{2} \mathrm{~S} \cdot \mathrm{m}^{-3} \cdot \mathrm{h}^{-1}\right)$ was lower than BTF1 $\left(272 \mathrm{~g} \mathrm{H}_{2} \mathrm{~S} \cdot \mathrm{m}^{-3} \cdot \mathrm{h}^{-1}\right)$. Comparison of 231 this result with previous studies shows that a maximum EC of $100 \mathrm{~g} \mathrm{H}_{2} \mathrm{~S} \mathrm{~m}^{-3} \mathrm{~h}^{-1}$ was found at $\mathrm{H}_{2} \mathrm{~S}$ concentrations 232 greater than 1500 ppmv using metallic pall rings as a filter bed, under mass transfer limiting conditions (Montebello 233 et al. 2013). A maximum EC of $24 \mathrm{~g} \mathrm{H}_{2} \mathrm{~S} \mathrm{~m}^{-3} \cdot \mathrm{h}^{-1}$ was achieved at $100 \% \mathrm{RE}$ in a laboratory biotrickling filter packed 234 with plastic pall rings (Jin et al. 2005). Similarly, (Fortuny et al. 2008) showed that a $200 \mathrm{~g} \mathrm{H}_{2} \mathrm{~S} \mathrm{~m}^{-3} \cdot \mathrm{h}^{-1}$ elimination capacity was observed at $\mathrm{H}_{2} \mathrm{~S}$ concentrations of 900-10,000 in a biotrickling filter at an empty bed retention time 236 (EBRT) of $180 \mathrm{~s}$.

237 Therefore, results indicate that the biofiltration system, containing stainless-steel pall rings as a filter material, was suitable for $\mathrm{H}_{2} \mathrm{~S}$ removal with an average $94.2 \%$ efficiency for $\mathrm{H}_{2} \mathrm{~S}$ inlet concentrations in the range of 900 to 1500 ppmv $\mathrm{H}_{2} \mathrm{~S}$ and has potential for industrial application. 


\section{Effect of sulfate concentrations and changes of $\mathrm{pH}$ on $\mathrm{H}_{2} \mathrm{~S}$ elimination}

242 The sulfate concentration in the recirculated liquid was evaluated in both BTFs because it is the final product of the $243 \mathrm{H}_{2} \mathrm{~S}$ biofiltration treatment process. In the presence of enough oxygen, the sulfide was oxidized to sulfate $\left(\mathrm{SO}^{2-}{ }_{4}\right)$ by 244 a mixed population of SOB, which is a water-soluble compound. The amount of sulfate that accumulated over a 90245 day period is shown in Fig. 8a and 8b. The results indicate that the sulfate concentration reached $33 \mathrm{~S}_{-} \mathrm{SO}^{2-}{ }_{4} \mathrm{~g} / \mathrm{L}$, and 246 there was $95 \% \mathrm{H}_{2} \mathrm{~S}$ removal efficiency in BTF1. While the sulfate concentration was $3.7 \mathrm{~S}^{-\mathrm{SO}^{2-}}{ }_{4} \mathrm{~g} / \mathrm{L}$ in BTF 2 , and its 247 removal efficiency for $\mathrm{H}_{2} \mathrm{~S}$ was $67 \%$.

248 According to this study and measurements, no significant effect was observed in the $\mathrm{H}_{2} \mathrm{~S}$ removal efficiency when the 249 sulfate content was as high as $33 \mathrm{~g} / \mathrm{L}$ (Fig.8). These results are consistent with (Fernández et al. 2014), who indicated that a sulfate concentration higher than $33 \mathrm{~g} / \mathrm{L}$ must be avoided. Above this level, the activity of the microorganisms was significantly reduced due to the presence of sulfate at a toxic level.

252 After 5 days of continuous operation of the biotrickling filter, a slightly faster decrease in pH from 7 to 1.5 was observed in BTF1 as shown in Fig.8a. However, the significant changes in $\mathrm{pH}$ did not have a substantial effect on the $\mathrm{H}_{2} \mathrm{~S}$ removal efficiency, probably because SOB can live in acidic environments having a wide $\mathrm{pH}$ range (1 to 8 ) (Robertson and Kuenen 2006). These results are similar to the (Chen et al. 2014) study in which combinations of bamboo charcoal and ceramist were used for the removal of $\mathrm{H}_{2} \mathrm{~S}$. In particular, it was found that the removal efficiency of $\mathrm{H}_{2} \mathrm{~S}$ did not change when the $\mathrm{pH}$ decreased from 7 to 3. As seen in the experiment of Sercu et al. (2005), the $\mathrm{pH}$ of the recirculated liquid did not affect the biotricking filter performance when decreased to 2-3 (Rodriguez et al. 2014). Such a low $\mathrm{pH}$ causes a drastic reduction in $\mathrm{H}_{2} \mathrm{~S}$ solubility in the liquid medium in BTF1 and hence some of the $\mathrm{H}_{2} \mathrm{~S}$ escapes without being treated. Therefore, the BTF2 with a $\mathrm{pH}$ of 7 captures $\mathrm{H}_{2} \mathrm{~S}$ and then oxidizes it to sulfate.

\section{Methane, $\mathrm{CO}_{2}$, and oxygen concentrations}

262 Purified biogas is mainly used as feedstock to produce alternative fuels. Conversion of both gases, i.e., methane $\left(\mathrm{CH}_{4}\right)$ 263 and carbon dioxide $\left(\mathrm{CO}_{2}\right)$, to alternative fuels such as methanol and syngas, will help to alleviate the greenhouse gas 264 (GHG) release and global warming impact (Zain and Mohamed 2018). Therefore, it is very important to keep the $\mathrm{CH}_{4}$ 265 and $\mathrm{CO}_{2}$ concentrations constant in the outlet gas from the biofiltration system.

266 During the biotrickling filter operation, the concentrations of the main biogas components, methane, and carbon 267 dioxide showed minor variations (Fig. 9). The average inlet concentrations of methane and carbon dioxide were 45.5 $268 \pm 3.9 \%(\mathrm{v} / \mathrm{v})$ and $35.0 \pm 2.9 \%(\mathrm{v} / \mathrm{v})$, respectively. While the treated biogas in BTF1 (Fig. 8a) had an average methane 
concentration of $45.4 \pm 3.7 \%(\mathrm{v} / \mathrm{v})$ and an average carbon dioxide concentration of $35.0 \pm 2.7 \%(\mathrm{v} / \mathrm{v})$ of the biogas.

270

271

272

273

274

275

276

277

278

279

280

281

282

283

284

285

286

287

288

289

290

291

292

293

294

295

296

The concentrations of methane and carbon dioxide in the biogas in BTF2 (Fig. 10b) showed the same behavior as in BTF1. The average concentrations of methane and carbon dioxide in the outlet were $46.5 \pm 2.9 \%(\mathrm{v} / \mathrm{v})$ and $35.8 \pm 1.9$ $\%(\mathrm{v} / \mathrm{v})$, respectively.

According to the results, there was no significant difference between the average concentrations of inlet and outlet methane and carbon dioxide in the BTF1 and BTF2. This indicates that the energetic content of the biogas was not reduced during the $\mathrm{H}_{2} \mathrm{~S}$ oxidation process in the biotrickling filter. The biotic process and the use of medium containing an inorganic carbon source did not affect the concentrations of methane and carbon dioxide in the biotrickling filters. Thus, the SOB is an autotroph organism capable of oxidizing such compounds as hydrogen sulfide from carbonate as an inorganic compound and does not use methane as a source of carbon and energy (Terrado et al. 2017).

There were no reductions in the concentrations of methane or carbon dioxide in the biogas. When compared to conventional aerobic biotrickling filters, maintaining the methane concentration is a major benefit. (Fernández et al. 2013). This fact demonstrated that the biofiltration system could be used efficiently for $\mathrm{H}_{2} \mathrm{~S}$ elimination while maintaining the energetic value of the biogas.

During the operation of an aerobic biotrickling filter system, air is supplied with the biogas stream to provide oxygen for biological oxidation and SOB microbial respiration. Oxygen control in the biotrickling filter is essential because oxygen deficiency causes a formation of elemental sulfur and subsequently increases clogging problems, while a high amount of oxygen means that the biogas is severely diluted and unwanted residual oxygen can be found in the outlet biogas. The landfill biogas does not contain enough oxygen to support complete $\mathrm{H}_{2} \mathrm{~S}$ bio-oxidation. Essentially, it requires an air/oxygen blower with security control to ensure that the air concentration does not exceed the lower explosive limit of methane in biogas of $9.2 \mathrm{~mol} \%$ (Schroeder et al. 2014). The addition of 4-6\% (v/v) air (0.8-1.2\% $(\mathrm{v} / \mathrm{v}) \mathrm{O}_{2}$ ) to biogas before biofiltration is to ensure proper sulfide conversion (Wellinger and Lindberg 2000). Soreanu et al. (2005) found that in a reactor with less than $3 \%(\mathrm{v} / \mathrm{v}) \mathrm{O}_{2},>90 \% \mathrm{H}_{2} \mathrm{~S}$ biological conversion was achieved. Schomaker et al. (2000) also suggested 5\% (v/v) air as being a low enough concentration of $\mathrm{O}_{2}$ in the inlet gas to biologically convert the $\mathrm{H}_{2} \mathrm{~S}$ to elemental sulfur instead of $\mathrm{SO}_{4}{ }^{2-}$, which requires a higher amount of $\mathrm{O}_{2}$. This difference in sulfide oxidation species was also reported by (Duan et al. 2005) where $0.1 \mathrm{mg} / \mathrm{L}$ was considered the oxygen limiting condition at which elemental sulfur would be the prominent product from sulfide oxidation. Sulfate would be the major product when sulfide was limited. 
In this study, oxygen was supplied with an average concentration of $2.1 \pm 0.9 \%(\mathrm{v} / \mathrm{v})$ into the BTF1 inlet to support the biological oxidation of $\mathrm{H}_{2} \mathrm{~S}$. As a result, the actual oxygen concentrations were found to be $1.8 \pm 0.8 \%(\mathrm{v} / \mathrm{v})$ and $1.6 \pm 0.7 \%(\mathrm{v} / \mathrm{v})$ in the BTF1 and the BTF2 outlets, respectively as shown in Fig. 10.

\section{Kinetic analysis of biodegradation}

In this experiment, the kinetic process of biological $\mathrm{H}_{2} \mathrm{~S}$ degradation was studied using a pilot-scale biotrickling filter. Two percent oxygen was supplied to the biotrickling filter for SOB microbial activity and respiration. The $\mathrm{H}_{2} \mathrm{~S}$ removal in the biotrickling filter system could be regarded as a simple enzyme-catalyzed reaction with one substrate and without inhibitor product (Michaelis-Menten equation).

The linear relationship between $1 / \mathrm{R}$ and $1 / \mathrm{C}_{\mathrm{ln}}$ in the biotrickling filter indicated in Fig. 11. The maximum removal rate ( $\mathrm{V}_{\max }$ ) and the half-saturation constant $\left(\mathrm{K}_{\mathrm{s}}\right)$ of $\mathrm{H}_{2} \mathrm{~S}$ were calculated from the regression analysis as $200 \mathrm{mg} \mathrm{H} \mathrm{H}_{2} \mathrm{~S} / \mathrm{L} / \mathrm{h}$ and 34.7 ppmv, respectively. Generally, the lower $\mathrm{K}_{\mathrm{s}}$ value, compared to the $\mathrm{H}_{2} \mathrm{~S}$ concentration range (900-1500 ppmv), is an indication of the affinity of the enzyme towards the substrate and the efficiency with which degradation will occur. Thus, the biotrickling filter showed a high capacity for $\mathrm{H}_{2} \mathrm{~S}$ oxidation. The kinetic parameters were within the range reported by other researchers. (Ma et al. 2006) reported a $\mathrm{V}_{\max }$ value of $666.7 \mathrm{mg} \mathrm{H}_{2} \mathrm{~S} /$ (L.d) with a $\mathrm{K}_{\mathrm{s}}$ value of $20.8 \mathrm{mg} / \mathrm{L}$. (Chung et al. 2001) reported a $\mathrm{V}_{\max }$ value of $1.11 \mathrm{~g}-\mathrm{S} / \mathrm{day} / \mathrm{kg}$ bead) in the biofilter and $\mathrm{K}_{\mathrm{s}}$ value of 34.6

312 ppm.

\section{Characterization of the liquid phase of the biotrickling filter in treating landfill biogas}

314 The liquid phase (nutrient solution) is an essential part in treating biogas. The nutrient solution is used to provide the necessary nutrients for the microorganisms, to control the $\mathrm{pH}$ of the reaction media and to solubilize the $\mathrm{H}_{2} \mathrm{~S}$ so that

316 it can be bio-transformed. In this study, the average characteristics of the liquid produced are based on the 317 measurement of $\mathrm{pH}, \mathrm{COD}$, sulfate concentration, and heavy metals of the percolate (Table 5). During the experiment 318 period, since a large amount of sulfuric acid had accumulated in the medium, the pH was quite acidic. The mixed wastewater from the discharges of biotrickling filters 1 and 2 had a $\mathrm{pH}$ of 5 . As a result, sulfate as a product of 320 microbial oxidation of $\mathrm{H}_{2} \mathrm{~S}$ could be responsible for the $\mathrm{pH}$ decrease.

321 Based on the characteristics of the mixed wastewater produced from the biofiltration system, it was observed that high concentrations of chrome, iron, and nickel were leached to the liquid. These metals were probably chemically or 323 biologically leached from the packing material (consisting essentially of stainless steel) at such acidic and oxidizing conditions (Montebello et al. 2014). 


\section{2}

The COD of the initial nutrition solution before recirculation was around $20 \mathrm{mg} / \mathrm{L}$. The COD of the liquid increased due to high concentrations of biomass released and organic content absorbed to reach $1520 \mathrm{mg} / \mathrm{L}$ after 6 months of operation. This value is higher than the COD concentration in the (Omri et al. 2013) study, where it was observed that the COD of the liquid increased from $20-30 \mathrm{mg} / \mathrm{L}$ to $350-680 \mathrm{mg} / \mathrm{L}$ at the outlet of the bed for 150 day of operation.

\section{CONCLUSIONS}

The results of this study show that a stable performance of a biotrickling filter system, packed with stainless-steel pall rings, for elimination of $\mathrm{H}_{2} \mathrm{~S}$ from landfill biogas, can be achieved in long-term operation. This system has the advantage of reaching relatively high removal efficiencies of $\mathrm{H}_{2} \mathrm{~S}$ with no reduction in methane concentration across the biotrickling filter. Removal efficiencies ranged between $94 \%$ and $97 \%$ for $\mathrm{H}_{2} \mathrm{~S}$ inlet concentrations in the range of 900 to 1500 ppmv. Approximately 50 ppmv of $\mathrm{H}_{2} \mathrm{~S}$ gas was detected in the outlet gas. The maximum elimination capacity of the biotrickling filter was found to be $272 \mathrm{~g} \mathrm{H}_{2} \mathrm{~S} / \mathrm{m}^{-3} / \mathrm{h}$. the performance of biotrickling filter was not affected when the $\mathrm{pH}$ of the recirculated liquid decreased to 2-3. Such low $\mathrm{pH}$ causes reduced solubility of $\mathrm{H}_{2} \mathrm{~S}$ in the liquid medium in BTF1, and hence some of the $\mathrm{H}_{2} \mathrm{~S}$ escapes without being treated. Therefore, the BTF2 with a pH of 7 captures $\mathrm{H}_{2} \mathrm{~S}$ and then oxidizes it to sulfate. As a result, biofiltration has proven to be a viable alternative to traditional treatment techniques for eliminating $\mathrm{H}_{2} \mathrm{~S}$ from landfill biogas. It was observed that high concentrations of chrome, iron, and nickel were leached to the liquid produced. These metals were probably chemically or biologically leached from the packing material (consisting essentially of stainless steel) at such acidic and oxidizing conditions.

\section{ACKNOWLEDGMENTS}

The authors would like to express their special thanks and gratitude to the Natural Science and Engineering Research Council of Canada (NSERC), Consortium de recherche et innovations en bioprocédés industriels au Québec (CRIBIQ), and Mathematics of Information Technology and Complex Systems (MITACS) for their financial support. The authors are also grateful to Olivier Savary, Carolina Lopera, Julien Duchaine Gauthier, and Nicolas Gobeil, Environmental Engineering Laboratory, Sherbrooke University for their help and support. 
351 Ethics approval and consent to participate

352 Not applicable.

353 Consent for publication

354 Not applicable.

355 Availability of data and materials

356 The datasets used and/or analyzed during the current study are available from the corresponding author on reasonable

357 request.

358 Competing interests

359 The authors declare that they have no competing interests.

$360 \quad$ Funding

361 This work was supported by the Natural Science and Engineering Research Council of Canada (NSERC), Consortium

362 de recherche et innovations en bioprocédés industriels au Québec (CRIBIQ), and Mathematics of Information

363 Technology and Complex Systems (MITACS).

364 Authors' contributions

365 All authors contributed to the study conception and design. Investigation, formal analysis and writing - original draft, 366 were performed by Rania Ibrahim. Abdessamad El Hassni contributed to the investigation, methodology and data 367 curation. Shahram Navaee-Ardeh contributed to the methodology, resources, and co-supervision. The supervision, 368 project administration, funding acquisition and writing - review \& editing were ensured by Hubert Cabana. All 369 authors read and approved the final manuscript.

\section{REFERENCE}

371 Abatzoglou N, Boivin S (2009) A review of biogas purification processes. Biofuels, Bioproducts and Biorefining 372 6:42-71. https://doi.org/10.1002/bbb.177

373 APHA: American Public Health Association, (1992). Standard method: examination of water and wastewater. 374 American Public Health Association $18^{\text {th }}$ ed. APHA, New York.

375 Bailón A L. (2007) An innovative biotrickling filter for $\mathrm{H}_{2} \mathrm{~S}$ removal from biogas. Biotech. Air Pollut. Control Proc. 376 2nd Int. Congr. Biotech. Air Pollution Control, A Coruña, Spain: C. Kennes and M. Veiga (Eds), Universidade da 377 Coruña; $215-24$. 
CEAEQ (2012). Centre d'expertise en analyse environnementale polyéthoxylé et de leurs produits de dégradation: dosage par chromatographie en phase liquide couplée à un spectromètre de masse en tandem Centre d'expertise en analyse environnementale du Québec.

Chaiprapat S, Mardthing R, Kantachote D, Karnchanawong S (2011) Removal of hydrogen sulfide by complete aerobic oxidation in acidic biofiltration. Process Biochemistry 46:344-352. https://doi.org/10.1016/j.procbio.2010.09.007.

Chen Y, Fan Z, Ma L, et al (2014) Performance of three pilot-scale immobilized-cell biotrickling filters for removal of hydrogen sulfide from a contaminated air steam. Saudi Journal of Biological Sciences 21:450-456. https://doi.org/10.1016/j.sjbs.2014.05.008.

Chung YC, Huang C, Tseng CP (2001) Biological elimination of $\mathrm{H}_{2} \mathrm{~S}$ and $\mathrm{NH}_{3}$ from wastegases by biofilter packed with immobilized heterotrophic bacteria. Chemosphere 43:1043-1050. https://doi.org/10.1016/S0045$\underline{6535(00) 00211-3}$

Cohen, Y. (2001). "Biofiltration - The treatment of fluids by microorganisms immobilized into the filter bedding material: a review." Bioresource Technology. 77, 257-274.

Duan H, Koe LCC, Yan R (2005) Treatment of $\mathrm{H}_{2} \mathrm{~S}$ using a horizontal biotrickling filter based on biological activated carbon: Reactor setup and performance evaluation. Applied Microbiology and Biotechnology 67:143-149. https://doi.org/10.1007/s00253-004-1771-7.

Dumont E (2015) $\mathrm{H}_{2} \mathrm{~S}$ removal from biogas using bioreactors: a review. International Journal of Energy and Environment 6:479-498

Dumont E, Ayala Guzman LM, Rodríguez Susa MS, Andrès Y (2012) $\mathrm{H}_{2} \mathrm{~S}$ biofiltration using expanded schist as packing material: Performance evaluation and packed-bed tortuosity assessment. Journal of Chemical Technology and Biotechnology 87:725-731. https://doi.org/10.1002/jctb.3713.

Fernández M, Ramírez M, Gómez JM, Cantero D (2014) Biogas biodesulfurization in an anoxic biotrickling filter packed with open-pore polyurethane foam. Journal of Hazardous Materials 264:529-535. https://doi.org/10.1016/j.jhazmat.2013.10.046.

Fernández M, Ramírez M, Pérez RM, et al (2013) Hydrogen sulphide removal from biogas by an anoxic biotrickling filter packed with Pall rings. Chemical Engineering Journal 225:456-463. https://doi.org/10.1016/j.cej.2013.04.020.

Fortuny M, Baeza JA, Gamisans X, et al (2008) Biological sweetening of energy gases mimics in biotrickling filters. Chemosphere 71:10-17. https://doi.org/10.1016/j.chemosphere.2007.10.072.

Hirai M, Ohtake M, Shoda M (1990) Removal kinetics of hydrogen sulfide, methanethiol and dimethyl sulfide by peat biofilters. Journal of Fermentation and Bioengineering 70:334-339. https://doi.org/10.1016/0922-338X(90)90145-M.

Jaber M, Anet B, Amrane A, et al (2014) Impact of nutrients supply and $\mathrm{pH}$ changes on the elimination of hydrogen sulfide, dimethyl disulfide and ethanethiol by biofiltration. Chemical Engineering Journal 258:420-426. https://doi.org/10.1016/j.cej.2014.07.085.

Jaber M, Couvert A, Amrane A, et al (2016) Biofiltration of $\mathrm{H}_{2} \mathrm{~S}$ in air-experimental comparisons of original packing materials and modeling. Biochemical Engineering Journal 112:153-160. https://doi.org/10.1016/j.bej.2016.04.020.

Jin Y, Veiga MC, Kennes C (2005) Autotrophic deodorization of hydrogen sulfide in a biotrickling filter. Journal of Chemical Technology and Biotechnology 80:998-1004. https://doi.org/10.1002/jctb.1275. 
Jirka AM, Carter MJ (1975) Micro semi-automated analysis of surface and wastewaters for chemical oxygen demand. Analytical Chemistry 47:1397-1402. https://doi.org/10.1021/ac60358a004.

418 Kennes C, Rene ER, Veiga MC (2009) Bioprocesses for air pollution control. Journal of Chemical Technology and Biotechnology 84:1419-1436. https://doi.org/10.1002/jctb.2216. Lastella G, Testa C, Cornacchia G, et al (2002) Anaerobic digestion of semi-solid organic waste: Biogas production and its purification. Energy Conversion and Management 43:63-75. https://doi.org/10.1016/S0196-8904(01)000114225.

423 Ma YL, Yang BL, Zhao JL (2006) Removal of $\mathrm{H}_{2} \mathrm{~S}$ by Thiobacillus denitrificans immobilized on different matrices. 424 Bioresource Technology 97:2041-2046. https://doi.org/10.1016/j.biortech.2005.09.023.

Montebello AM, Baeza M, Lafuente J, Gabriel D (2010) Monitoring and performance of a desulphurizing biotrickling filter with an integrated continuous gas/liquid flow analyser. Chemical Engineering Journal 165:500-507. 427 https://doi.org/10.1016/j.cej.2010.09.053.

Montebello AM, Bezerra T, Rovira R, et al (2013) Operational aspects, $\mathrm{pH}$ transition and microbial shifts of a $\mathrm{H}_{2} \mathrm{~S}$ desulfurizing biotrickling filter with random packing material. Chemosphere 93:2675-2682. https://doi.org/10.1016/j.chemosphere.2013.08.052.

Montebello AM, Mora M, López LR, et al (2014) Aerobic desulfurization of biogas by acidic biotrickling filtration in 432 a randomly packed reactor. Journal of Hazardous Materials 280:200-208. 433 https://doi.org/10.1016/j.jhazmat.2014.07.075.

434 Namgung HK, Ahn H-Y, Song J-H (2012) Development of a two-phase bioreactor for the biological removal of 435 hydrogen sulfide from biogas. Energy Procedia 14:1143-1148. https://doi.org/doi:10.1016/j.egypro.2011.12.887.

436 Omri I, Aouidi F, Bouallagui H, et al (2013) Performance study of biofilter developed to treat $\mathrm{H}_{2} \mathrm{~S}$ from wastewater 437 odour. Saudi Journal of Biological Sciences 20:169-176. https://doi.org/10.1016/j.sjbs.2013.01.005.

438 Oyarzún P, Arancibia F, Canales C, Aroca GE (2003) Biofiltration of high concentration of hydrogen sulphide using 439 Thiobacillus thioparus. Process Biochemistry 39:165-170. https://doi.org/10.1016/S0032-9592(03)00050-5.

440 Potivichayanon S, Pokethitiyook P, Kruatrachue M (2006) Hydrogen sulfide removal by a novel fixed film 441 bioscrubber system. Process Biochemistry 41:708-715. https://doi.org/10.1016/j.procbio.2005.09.006.

442 Rasi S, Veijanen A, Rintala J (2007) Trace compounds of biogas from different biogas production plants. Energy $443 \quad 32: 1375-1380$. https://doi.org/10.1016/j.energy.2006.10.018.

444 Rattanapan C, Boonsawang P, Kantachote D (2009) Removal of $\mathrm{H}_{2} \mathrm{~S}$ in down-flow GAC biofiltration using sulfide 445 oxidizing bacteria from concentrated latex wastewater. Bioresource Technology 100:125-130. 446 https://doi.org/10.1016/j.biortech.2008.05.049.

447 Robertson LA, Kuenen JG (2006) The Genus Thiobacillus. The Prokaryotes 812-827. https://doi.org/10.1007/0-387$448 \quad 30745-137$.

449 Rodriguez G, Dorado AD, Fortuny M, et al (2014) Biotrickling filters for biogas sweetening: Oxygen transfer 450 improvement for a reliable operation. Process Safety and Environmental Protection 92:261-268. 451 https://doi.org/10.1016/j.psep.2013.02.002. 
Schedel M, Legall J, Baldensperger J (1975) Sulfur metabolism in thiobacillus denitrificans - evidence for the presence of a sulfite reductase activity. Archives of Microbiology 105:339-341. https://doi.org/10.1007/BF00447155.

Schomaker AHHM, Boerboom AAM, Visser A, Pfeifer AE (2000) Anaerobic digestion of agro-industrial wastes: Information networks technical summary on gas treatment project fair-Ct96-2083 (Dg12-Ssmi) Anaerobic digestion of agro-industrial wastes: Information networks technical summary on gas treatment AD-NETT. 2083

Schroeder V, Schalau B, Molnarne M (2014) Explosion protection in biogas and hybrid power plants. Procedia Engineering 84:259-272. https://doi.org/10.1016/j.proeng.2014.10.433.

Sercu B, Núñez D, van Langenhove H, et al (2005) Operational and microbiological aspects of a bioaugmented twostage biotrickling filter removing hydrogen sulfide and dimethyl sulfide. Biotechnology and Bioengineering 90:259269. https://doi.org/10.1002/bit.20443.

Soreanu G, Béland M, Falletta P, et al (2009) Evaluation of different packing media for anoxic $\mathrm{H}_{2} \mathrm{~S}$ control in biogas. Environmental Technology 30:1249-1259. https://doi.org/10.1080/09593330902998314.

Soreanu G, Falletta P, Béland M, Seto P (2008) Study on the performance of an anoxic biotrickling filter for the removal of hydrogen sulphide from biogas. Water Quality Research Journal of Canada 43:211-218. https://doi.org/10.2166/warj.2008.024.

Tang K, Baskaran V, Nemati M (2009) Bacteria of the sulphur cycle: An overview of microbiology, biokinetics and their role in petroleum and mining industries. Biochemical Engineering Journal 44:73-94. https://doi.org/10.1016/j.bej.2008.12.011.

Terrado R, Pasulka AL, Lie AAY, et al (2017) Autotrophic and heterotrophic acquisition of carbon and nitrogen by a mixotrophic chrysophyte established through stable isotope analysis. ISME Journal 11:2022-2034. https://doi.org/10.1038/ismej.2017.68.

Tomàs M, Fortuny M, Lao C, et al (2009) Technical and economical study of a full-scale biotrickling filter for $\mathrm{H}_{2} \mathrm{~S}$ removal from biogas. Water Practice and Technology 4:2. https://doi.org/10.2166/wpt.2009.026.

Vikromvarasiri N, Champreda V, Boonyawanich S, Pisutpaisal N (2017) Hydrogen sulfide removal from biogas by biotrickling filter inoculated with Halothiobacillus neapolitanus. International Journal of Hydrogen Energy 42:1842518433. https://doi.org/10.1016/j.ijhydene.2017.05.020.

Wellinger A, Lindberg A (2000) Biogas upgrading and utilisation. IEA Bioenergy 3-20

Wilen B, Balmer P (1999) The effect of dissolved oxygen concentration on the activated sludge process. War Res $33: 391-400$

Zain MM, Mohamed AR (2018) An overview on conversion technologies to produce value added products from $\mathrm{CH}_{4}$ and $\mathrm{CO}_{2}$ as major biogas constituents. Renewable and Sustainable Energy Reviews 98:56-63. https://doi.org/10.1016/j.rser.2018.09.003. 


\section{$485 \quad$ List of Tables}

486 Table 1: The experimental conditions of the laboratory test.

487 Table 2: Physical characteristics of the stainless-steel pall rings.

488 Table 3: The operational conditions of BTF1 and BTF2.

489 Table 4. Comparison of the $\mathrm{H}_{2} \mathrm{~S}$ elimination capacity of a lab-scale reactor with previous studies.

490 Table 5: Average characteristics of the liquid phase. 


\section{List of Figures}

493 Figure 1. A laboratory-scale bioreactor.

494 Figure 2. Stainless-steel pall rings (DN16).

495 Figure 3. Pilot-scale biotrickling filter in landfill site packed with stainless-steel pall rings (DN16).

496 Figure 4. Evolution of sulfate and biomass as a function of time during acclimation tests $\left(\mathrm{T}=25^{\circ} \mathrm{C}, 60 \mathrm{rpm}\right)$.

497 Figure 5. Monitoring the $\mathrm{H}_{2} \mathrm{~S}$ concentration at the inlet and outlet of the bioreactor and the rate of elimination. $(\mathrm{T}=$ $49825^{\circ} \mathrm{C}, 60 \mathrm{rpm}$, Initial biomass: OD600 $=3.75$ ).

499 Figure 6. Evolution of $\mathrm{pH}$, sulfate ion concentration and biomass concentration $\left(\mathrm{T}=25^{\circ} \mathrm{C}, 60 \mathrm{rpm}\right.$, Initial biomass:

$500 \mathrm{OD} 600=3.75$ ). The points in red correspond to the times when the culture medium was renewed.

501 Figure 7. The removal efficiency of $\mathrm{H}_{2} \mathrm{~S}$ in the two biotrickling filters. (a) Biotrickling filter 1, and (b) Biotrickling 502 filter 2.

503 Figure 8. The removal efficiency of $\mathrm{H}_{2} \mathrm{~S}$, cumulative sulfate $\mathrm{SO}_{4}{ }^{2-} / \mathrm{g} / \mathrm{L}$ and $\mathrm{pH}$ changes in two biotrickling filters. 504 (a) Biotrickling filter 1, and (b) Biotrickling filter 2.

505 Figure 9. Methane and carbon dioxide composition in \% (v/v). (a) Biotrickling filter 1, and (b) Biotrickling filter 2.

506 Figure 10. Oxygen concentration during the operation of two biotrickling filters.

507 Figure 11. The linear relationship between $1 / R$ and $1 / C_{l n}$ for $\mathrm{H}_{2} \mathrm{~S}$ degradation in the pilot scale biotrickling filter. 
Table 1 The experimental conditions of the laboratory test.

510

511

512

513

514

515

516

517

523

524

Table 2 Physical characteristics of the stainless-steel pall rings.

\begin{tabular}{ll}
\hline Physical characteristics & \\
\hline Nominal diameter $(\mathrm{mm})$ & $\mathrm{DN} 16$ \\
Diameter $\times$ Height $\times$ Thickness $(\mathrm{mm})$ & $16 \times 16 \times 0.4$ \\
Porosity $(\%)$ & 95 \\
Specific surface $\operatorname{area}\left(\mathrm{m}^{2} / \mathrm{m}^{3}\right)$ & 362 \\
Bulk density $\left(\mathrm{Kg} / \mathrm{m}^{3}\right)$ & 396 \\
\hline
\end{tabular}

Table 3 The operational conditions of BTF1 and BTF2.

\begin{tabular}{lll}
\hline Parameters & BTF1 & BTF2 \\
\hline Dimensions & $1.5 \mathrm{~m} \times 0.4 \mathrm{~m}$ & $1.3 \mathrm{~m} \times 0.2 \mathrm{~m}$ \\
Effective volume (L) & 110 & 25 \\
Hydraulic retention time @ $1 \mathrm{scfm}$ & $3.9 \mathrm{~min}$ & $0.9 \mathrm{~min}$ \\
$\mathrm{pH}$ & 2 & 7 \\
Concentration of inlet $\mathrm{H}_{2} \mathrm{~S}(\mathrm{ppmv})$ & 900 & 100 \\
Air humidity & $<4 \%$ & -- \\
\hline
\end{tabular}

Table 4 Comparison of the $\mathrm{H}_{2} \mathrm{~S}$ elimination capacity of a lab-scale reactor with previous studies.

\begin{tabular}{|c|c|c|c|c|c|}
\hline $\begin{array}{c}\text { Biogas } \\
\text { composition }\end{array}$ & $\begin{array}{c}\text { Inlet } \mathrm{H}_{2} \mathrm{~S} \\
\text { concentration } \\
\text { (ppmv) }\end{array}$ & EBRT & $\begin{array}{c}\mathrm{EC} \\
\mathrm{gm}^{-3} h^{-1}\end{array}$ & $\mathrm{RE}$ & Ref. \\
\hline $\mathrm{H}_{2} \mathrm{~S}+\mathrm{N}_{2}$ & $10-100$ & $12.71-31.77 \mathrm{~s}$ & 19.24 & $98 \%$ & (Potivichayanon et al. 2006) \\
\hline $\begin{array}{c}\mathrm{N}_{2}(65 \%)+\mathrm{CO}_{2} \\
(35 \%)\end{array}$ & 1000 & $69 \mathrm{~s}$ & 32.5 & 99 & Bailón 2007 \\
\hline \multicolumn{6}{|l|}{$\mathrm{H}_{2} \mathrm{~S}$ (traces) } \\
\hline $\mathrm{H}_{2} \mathrm{~S}+\mathrm{Air}$ & $10-90$ & $9-60 \mathrm{~s}$ & 32.5 & $98.3 \%$ & Namini et al., 2008 \\
\hline Real biogas & $1000-4000$ & $10.29-72 \mathrm{~min}$ & 14.58 & 99 & (Soreanu et al. 2008) \\
\hline $\mathrm{H}_{2} \mathrm{~S}+\mathrm{N}_{2}$ & $2,000-8,000$ & 180 & 50 & 100 & Montebello et al. 2010 \\
\hline Synthetic Biogas & $0-2040$ & $120 \mathrm{~s}$ & 78.57 & $93.6 \%$ & (Vikromvarasiri et al. 2017) \\
\hline Synthetic biogas & $730-2000$ & $1-2 \mathrm{~min}$ & 50 & 99 & This study \\
\hline
\end{tabular}

Volume (L)

Flow rate $(\mathrm{L} / \mathrm{min})$

time

Gas pressure before injection in the reactor (atm)

Concentration of $\mathrm{H}_{2} \mathrm{~S}$ (ppmv)

Concentration of $\mathrm{CO}_{2}(\% \mathrm{v} / \mathrm{v})$

Air humidity
Value

$0.5-1$

$1-2$ min

Atmosphere

$730-2000$

20

Balance 100\%

\begin{tabular}{ll}
\hline Parameters & Value \\
\hline Volume $(\mathrm{L})$ & 1 \\
Flow rate $(\mathrm{L} / \mathrm{min})$ & $0.5-1$ \\
Retention time & $1-2 \mathrm{~min}$ \\
Reactor pressure $(\mathrm{atm})$ & Atmosphere \\
Gas pressure before injection in the reactor $(\mathrm{atm})$ & 1.7 \\
Concentration of $\mathrm{H}_{2} \mathrm{~S}(\mathrm{ppmv})$ & $730-2000$ \\
Concentration of $\mathrm{CO}_{2}(\% \mathrm{v} / \mathrm{v})$ & 20 \\
Air humidity & Balance $100 \%$ \\
\hline
\end{tabular}


Table 5 Average characteristics of the liquid phase.

528

\begin{tabular}{ll}
\hline Parameters & Value \\
\hline $\mathrm{pH}$ & 5 \\
Chemical oxygen demand (COD) & $1520 \mathrm{mg} / \mathrm{L}$ \\
Total suspended solid (TSS) & $143 \mathrm{mg} / \mathrm{L}$ \\
Volatile suspended solid (VSS) & $47 \mathrm{mg} / \mathrm{L}$ \\
Sulfate ion (SO $4^{2-}$ ) & $22200 \mathrm{mg} / \mathrm{L}$ \\
Chrome (Cr) & $351 \mathrm{mg} / \mathrm{L}$ \\
Calcium (Ca) & $42.9 \mathrm{mg} / \mathrm{L}$ \\
Iron (Fe) & $1500 \mathrm{mg} / \mathrm{L}$ \\
Potassium (K) & $440 \mathrm{mg} / \mathrm{L}$ \\
Nickel (Ni) & $185 \mathrm{mg} / \mathrm{L}$ \\
Magnesium (Mg) & $54.5 \mathrm{mg} / \mathrm{L}$ \\
Manganese (Mn) & $22.9 \mathrm{mg} / \mathrm{L}$ \\
Phosphorus (P) & $440 \mathrm{mg} / \mathrm{L}$ \\
\hline
\end{tabular}



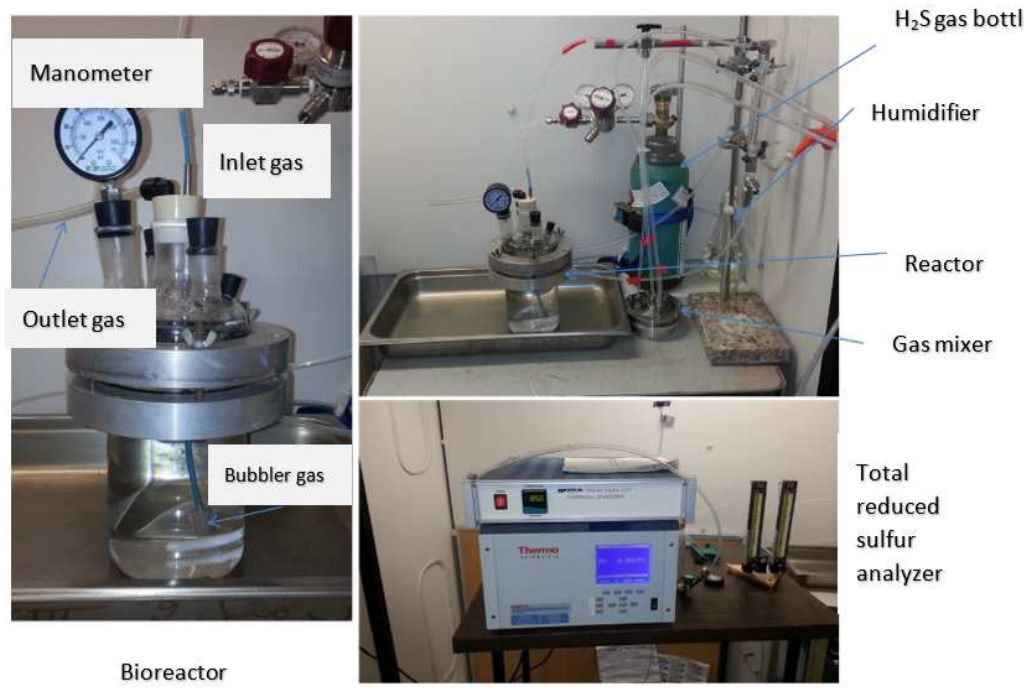

Figure 1 A laboratory scale bioreactor.

532

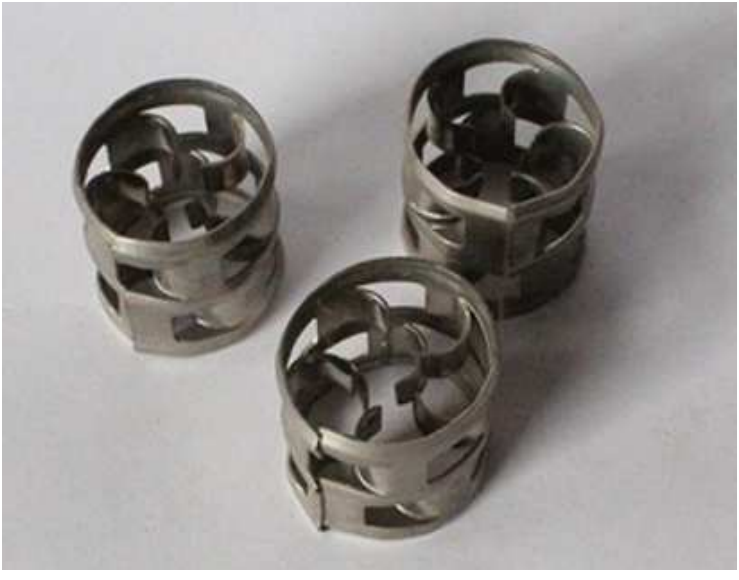

Figure 2 Stainless-steel pall rings (DN16). 


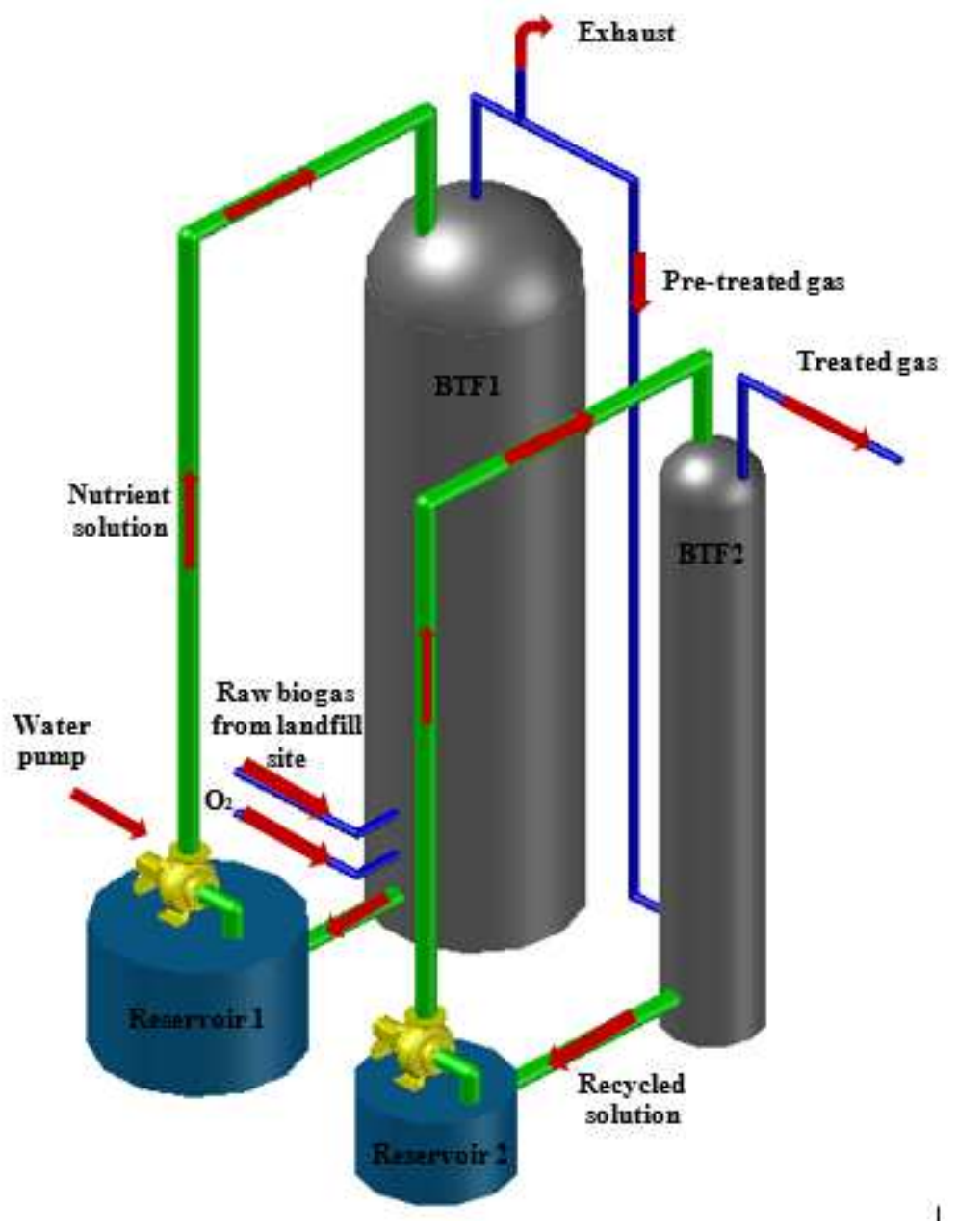

Figure 3 Pilot-scale biotrickling filter in landfill site packed with stainless-steel pall rings (DN16).

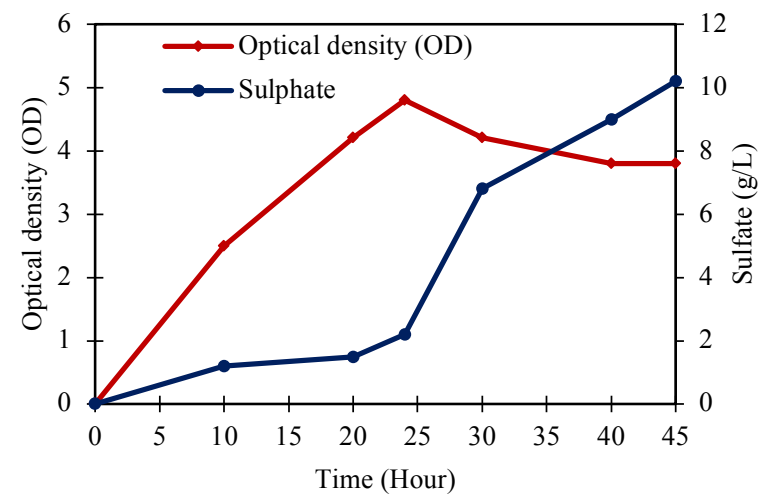

Figure 4 Evolution of sulfate and biomass as a function of time during acclimation tests $\left(\mathrm{T}=25^{\circ} \mathrm{C}, 60 \mathrm{rpm}\right)$. 


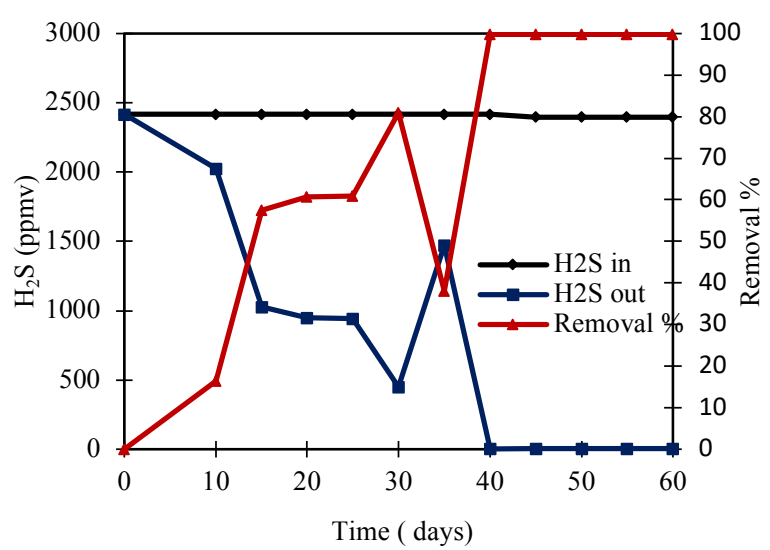

541

542

543
Figure 5 Monitoring the $\mathrm{H}_{2} \mathrm{~S}$ concentration at the inlet and outlet of the bioreactor and the rate of elimination. $(\mathrm{T}=$ $25^{\circ} \mathrm{C}, 60$ rpm, Initial biomass: OD600 $=3.75$ ).

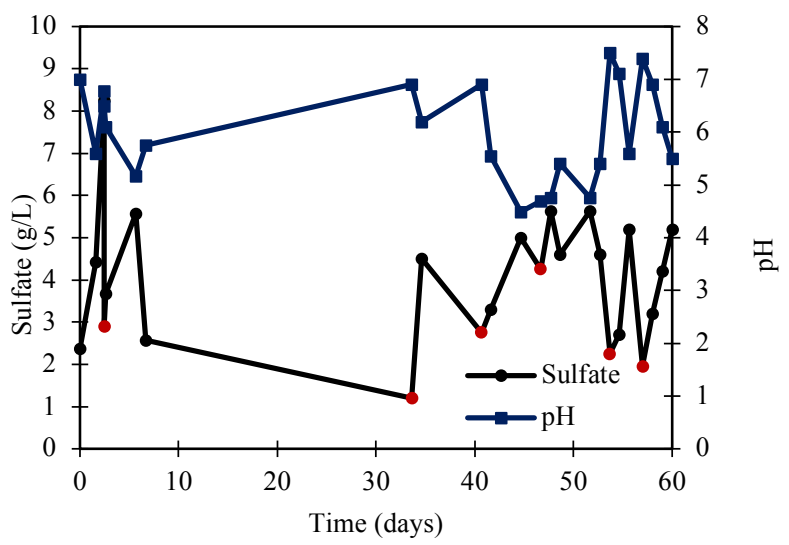

(a)

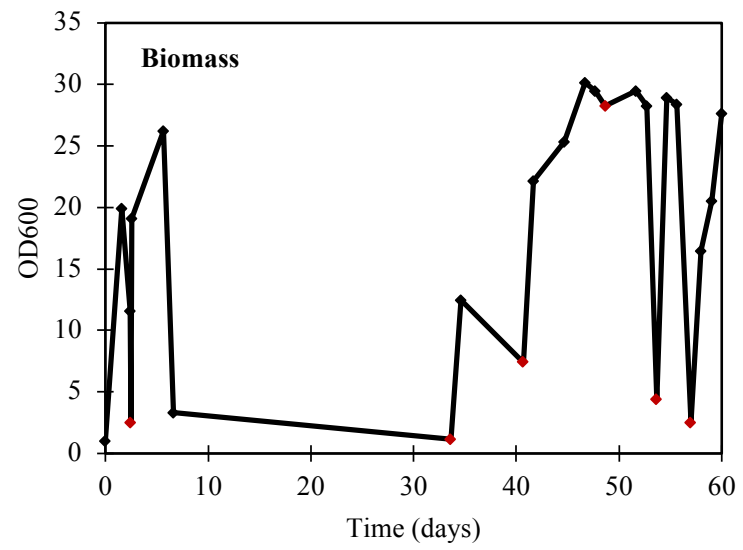

(b)

Figure 6 Evolution of $\mathrm{pH}$, sulfate ion concentration and biomass concentration $\left(\mathrm{T}=25^{\circ} \mathrm{C}, 60 \mathrm{rpm}\right.$, Initial biomass: OD600 $=3.75$ ). The points in red correspond to the times when the culture medium was renewed. 


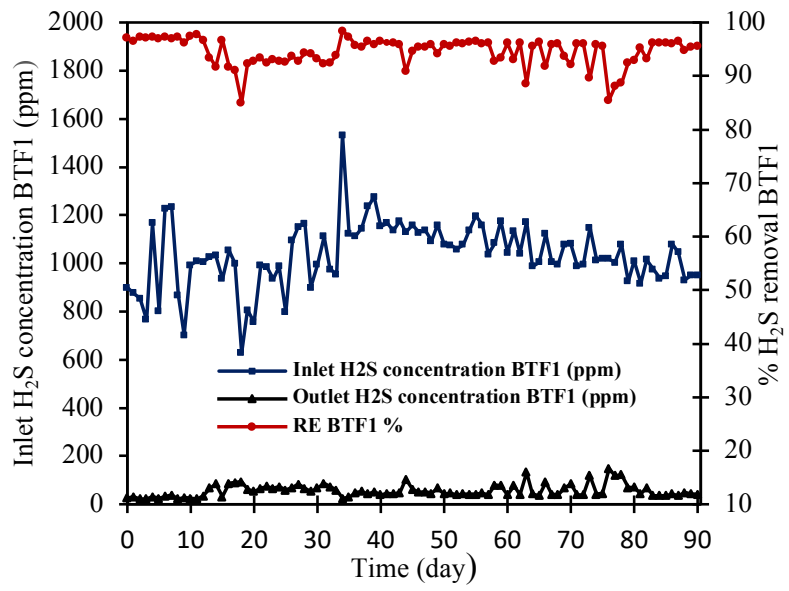

(a)

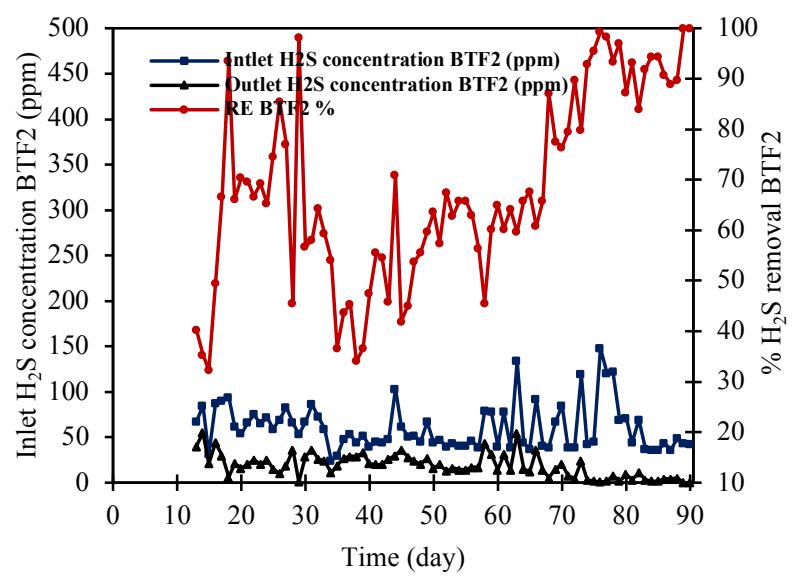

Figure 7 The removal efficiency of $\mathrm{H}_{2} \mathrm{~S}$ in the two biotrickling filters. (a) Biotrickling filter 1, and (b) Biotrickling filter 2. 


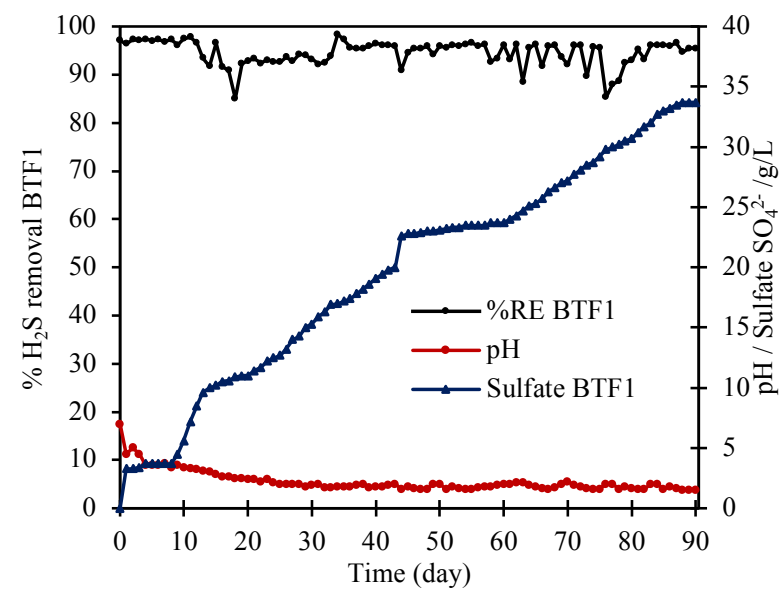

(a)

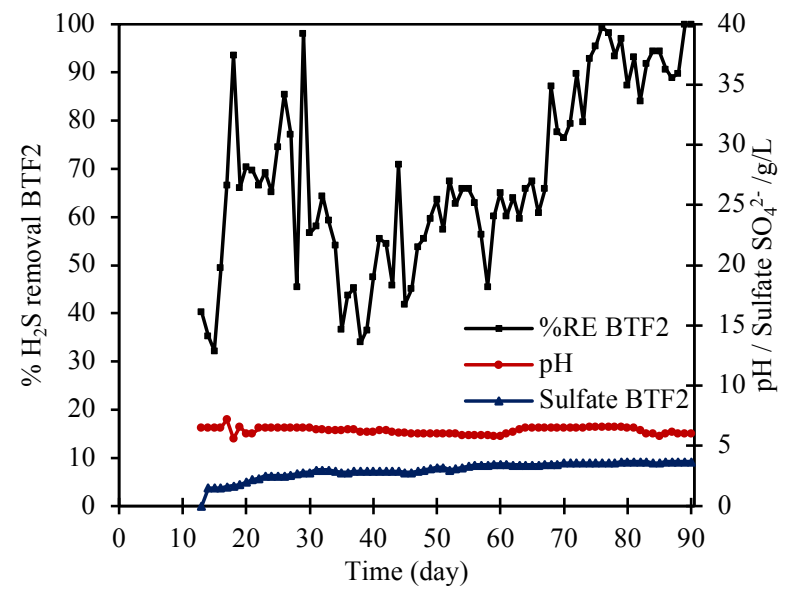

(b)

Figure 8 The removal efficiency of $\mathrm{H}_{2} \mathrm{~S}$, cumulative sulfate $\mathrm{SO}_{4}{ }^{2-} / \mathrm{g} / \mathrm{L}$ and $\mathrm{pH}$ changes in two biotrickling filters. (a) Biotrickling filter 1, and (b) Biotrickling filter 2. 


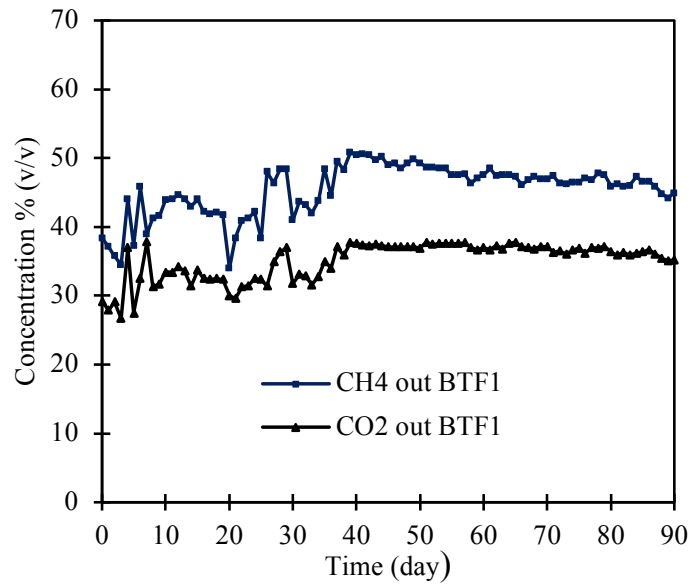

(a)

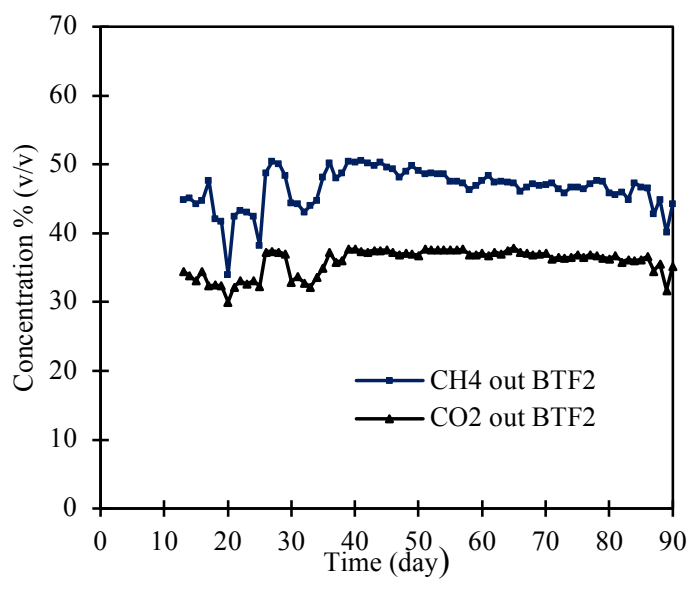

(b)

Figure 9 Methane and carbon dioxide composition in \% (v/v). (a) Biotrickling filter 1, and (b) Biotrickling 568 filter 2. 


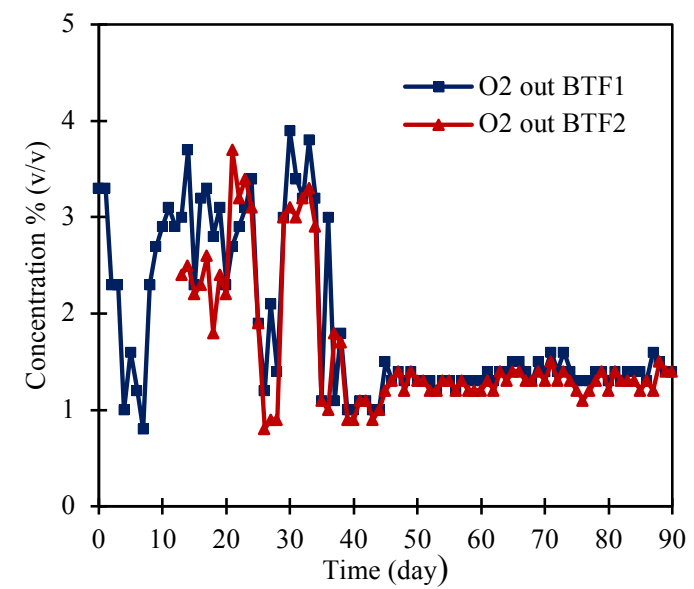

Figure 10 Oxygen concentration during operation of two biotrickling filters.

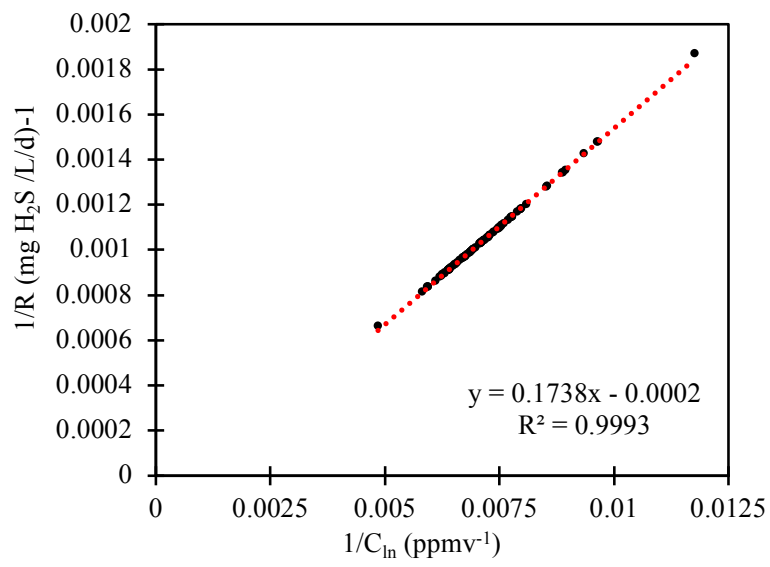

574 Figure 11 The linear relationship between $1 / R$ and $1 / C_{l n}$ for $\mathrm{H}_{2} \mathrm{~S}$ degradation in the pilot scale biotrickling 


\section{Figures}

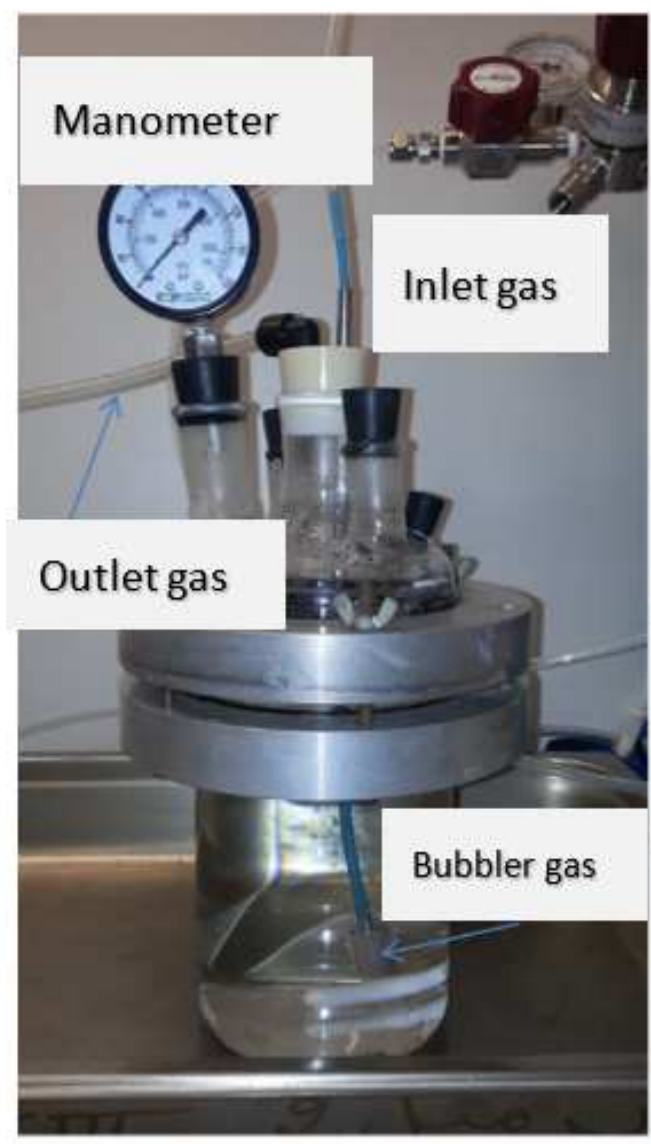

Bioreactor

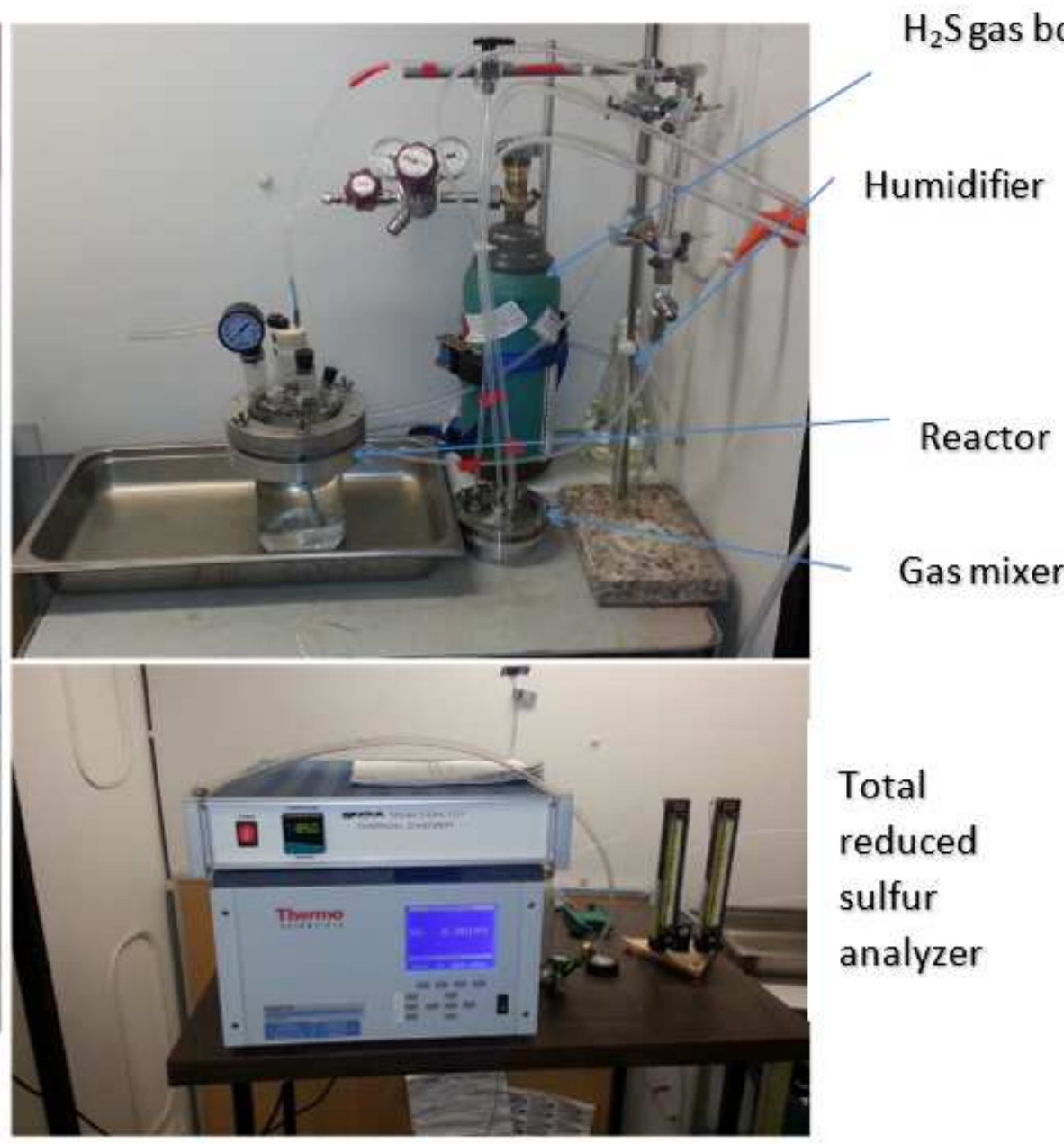

Figure 1

A laboratory scale bioreactor.

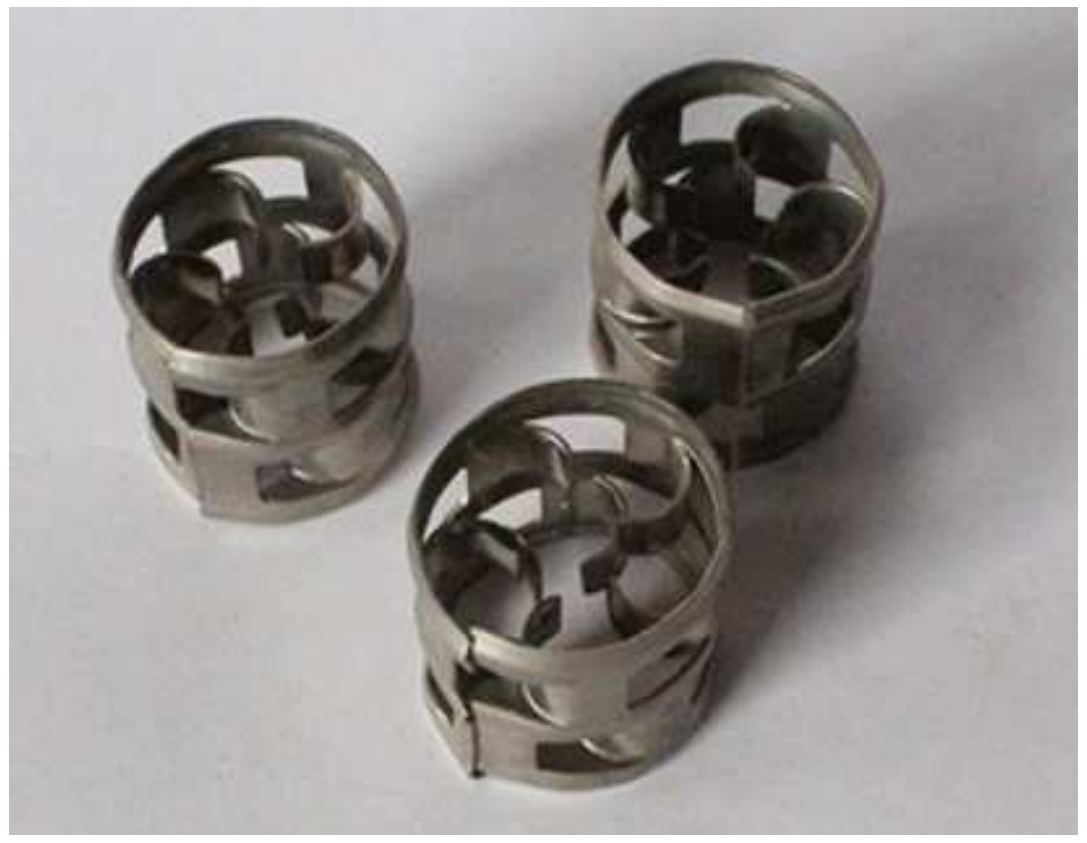


Figure 2

Stainless-steel pall rings (DN16).

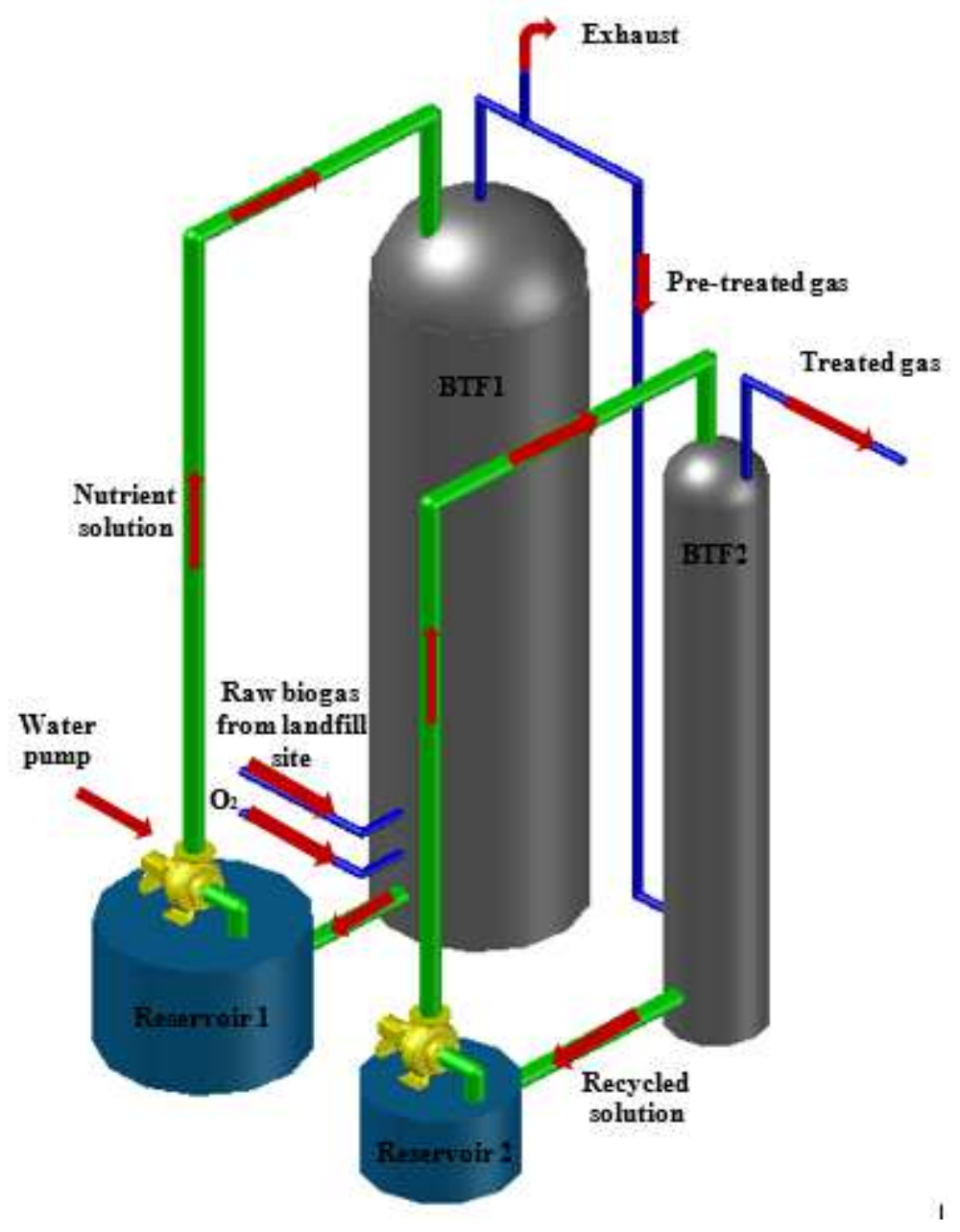

Figure 3

Pilot-scale biotrickling filter in landfill site packed with stainless-steel pall rings (DN16).

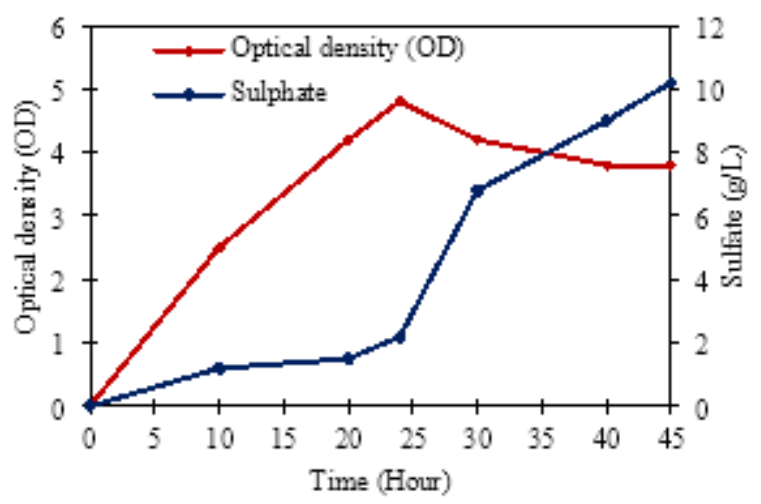

Figure 4 
Evolution of sulfate and biomass as a function of time during acclimation tests ( $\left.T=25^{\circ} \mathrm{C}, 60 \mathrm{rpm}\right)$.

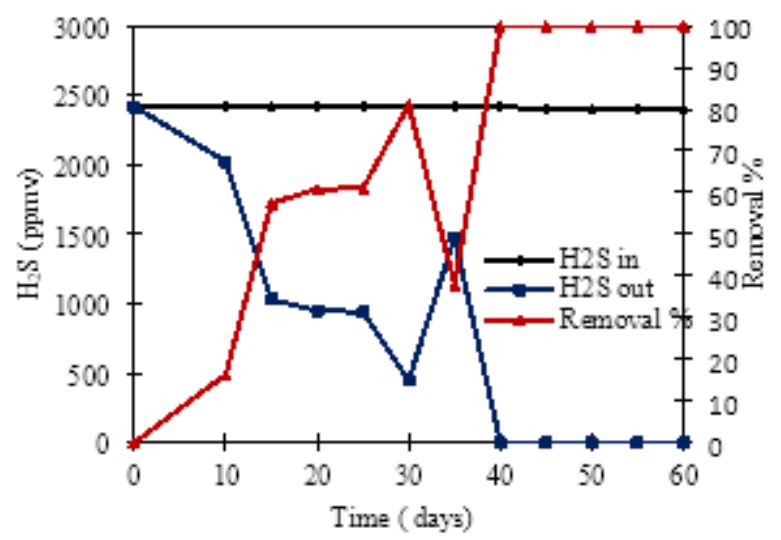

\section{Figure 5}

Monitoring the $\mathrm{H} 2 \mathrm{~S}$ concentration at the inlet and outlet of the bioreactor and the rate of elimination. $(\mathrm{T}=$ $25^{\circ} \mathrm{C}, 60 \mathrm{rpm}$, Initial biomass: OD600 $=3.75$ ). 


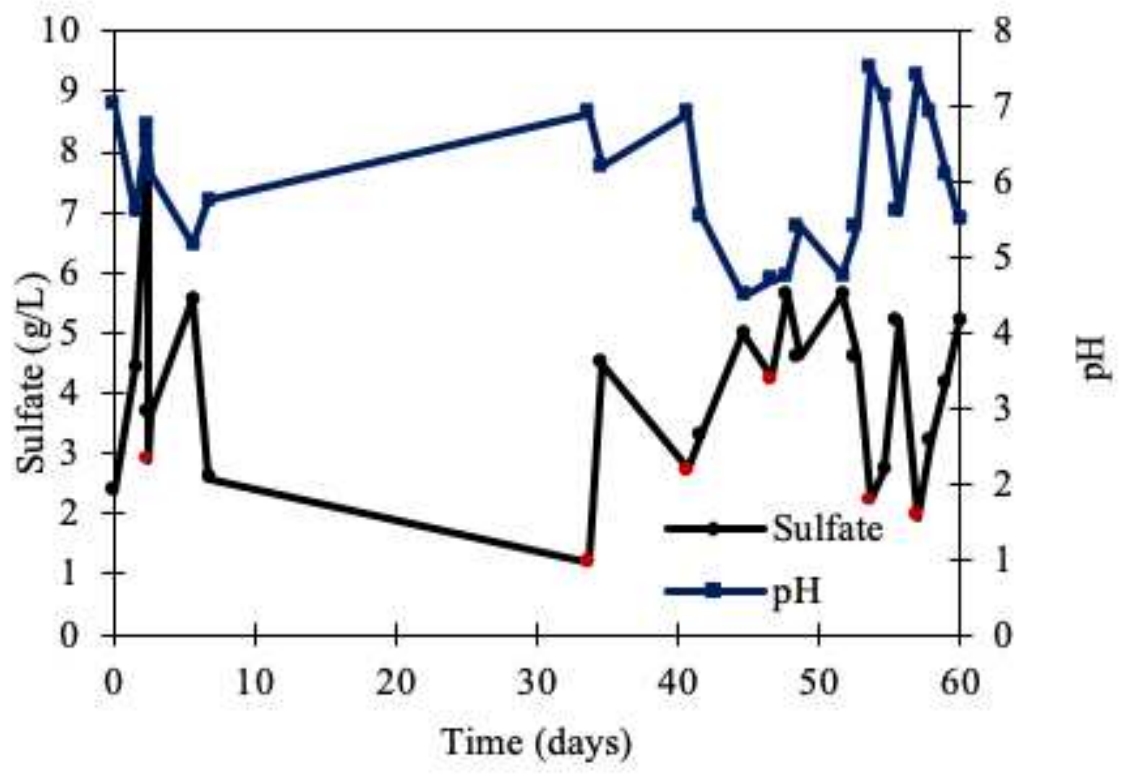

(a)

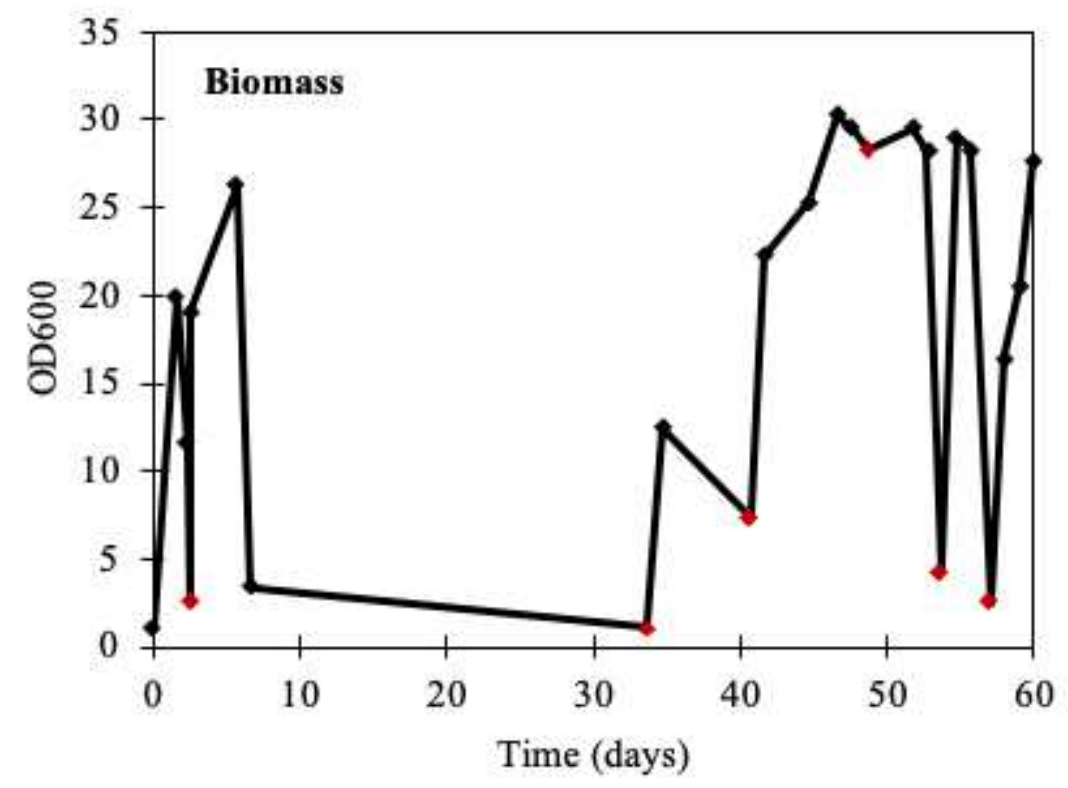

(b)

Figure 6

Evolution of $\mathrm{pH}$, sulfate ion concentration and biomass concentration $\left(\mathrm{T}=25^{\circ} \mathrm{C}, 60 \mathrm{rpm}\right.$, Initial biomass: OD600 $=3.75$ ). The points in red correspond to the times when the culture medium was renewed. 


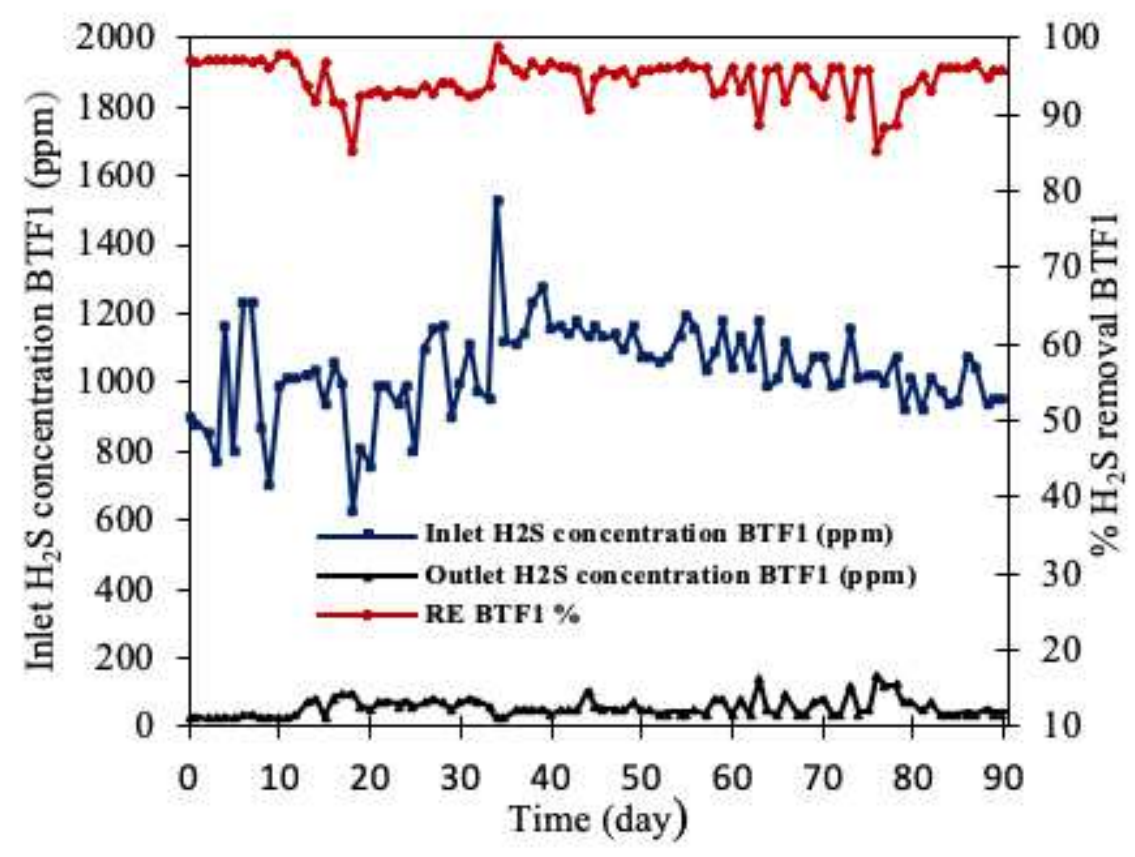

(a)

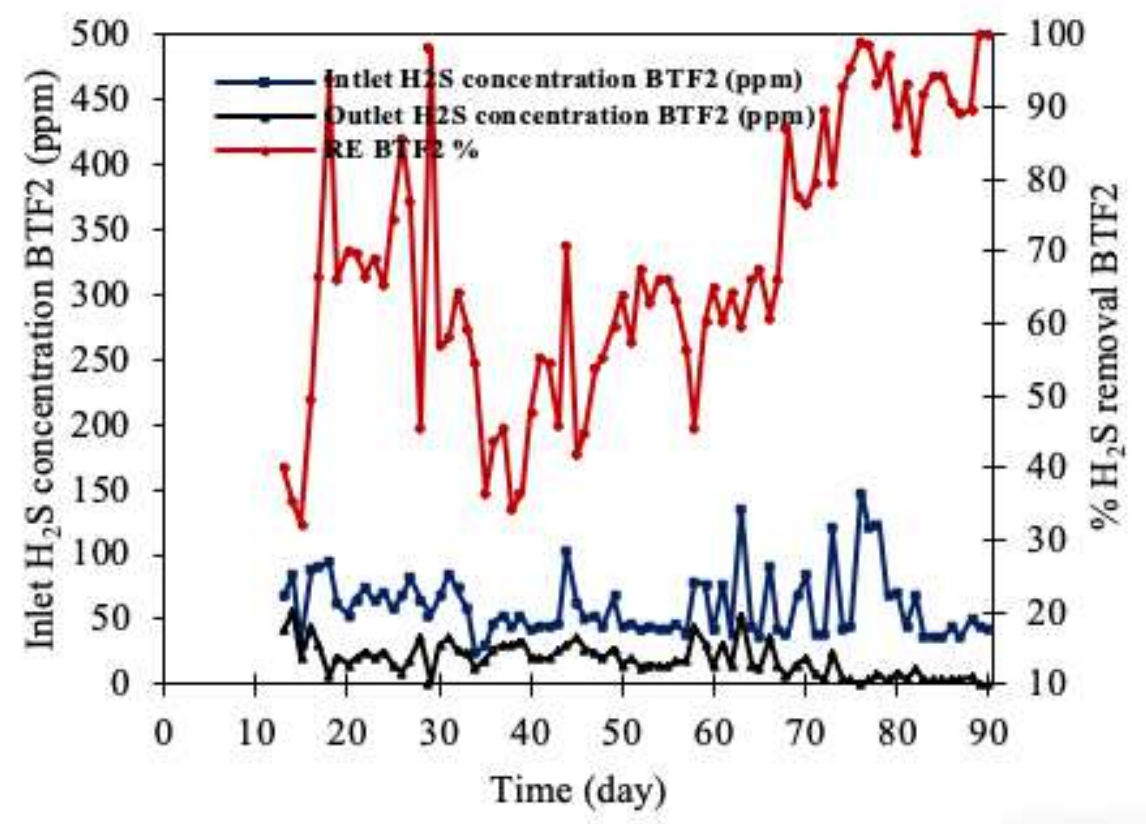

Figure 7

The removal efficiency of H2S in the two biotrickling filters. (a) Biotrickling filter 1, and (b) Biotrickling filter 2 . 


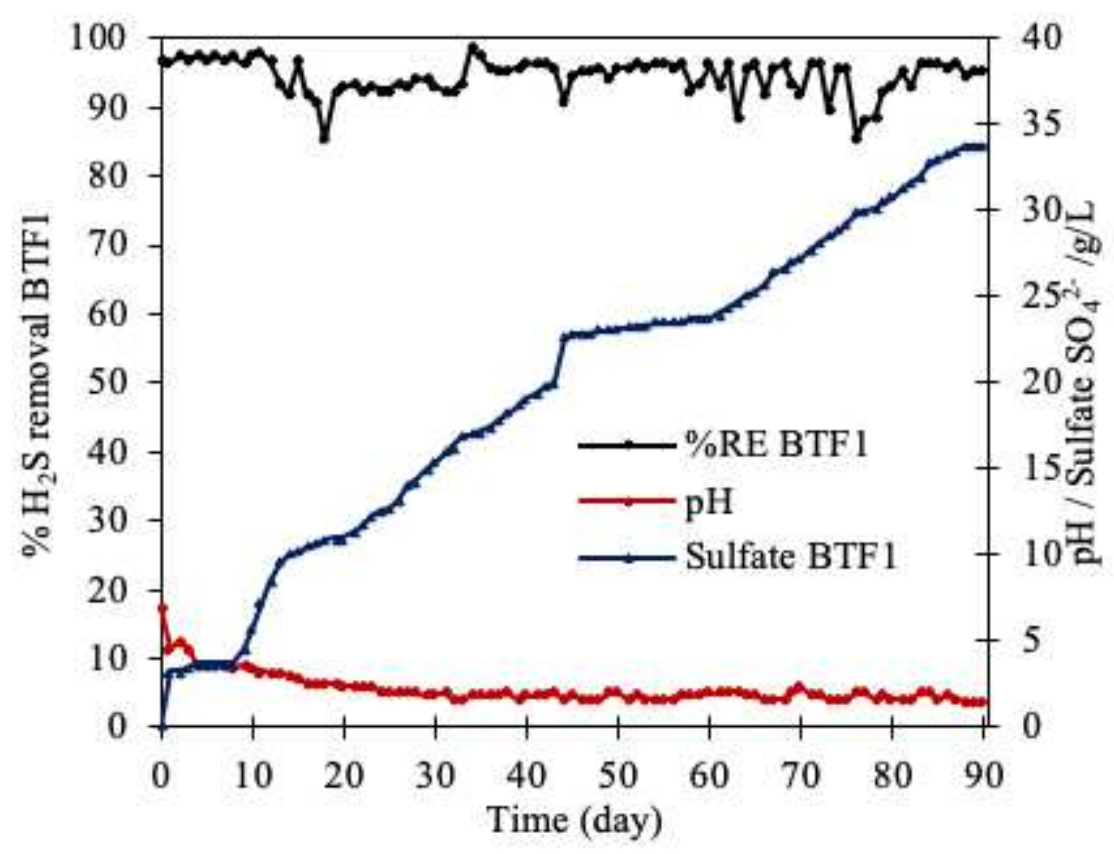

(a)

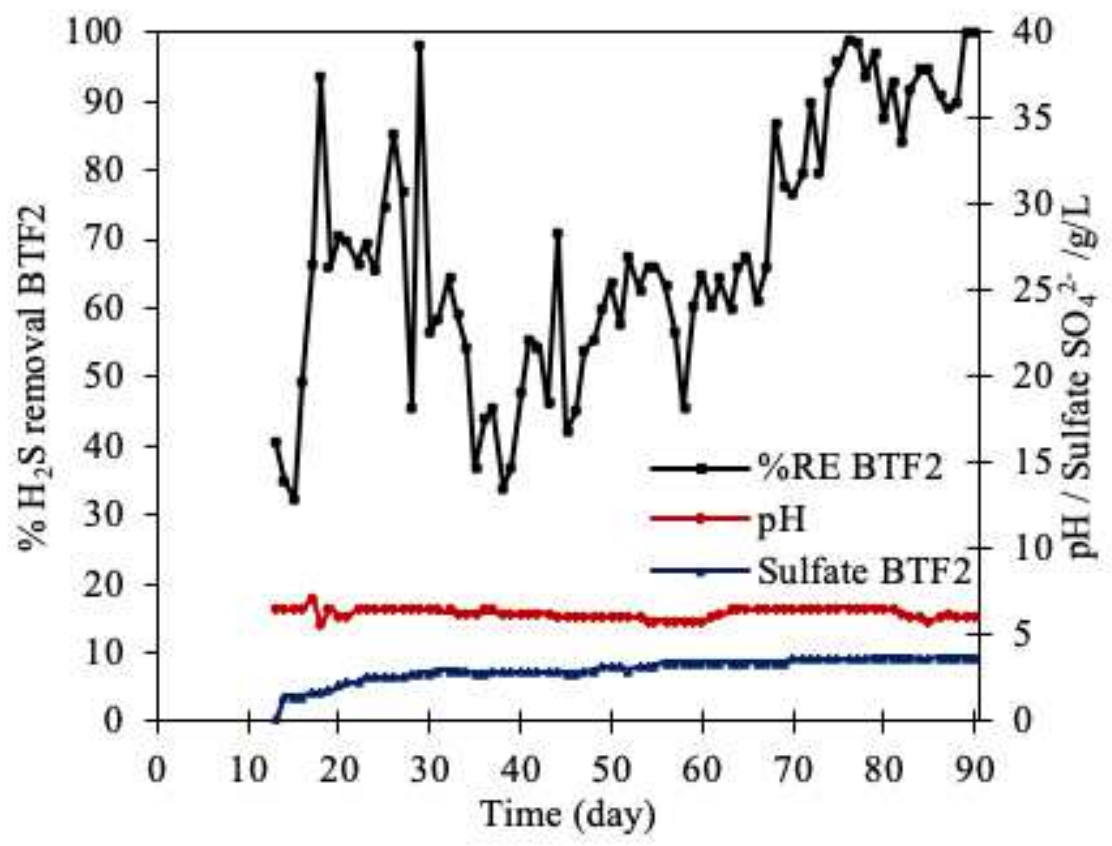

(b)

Figure 8

The removal efficiency of $\mathrm{H} 2 \mathrm{~S}$, cumulative sulfate $\mathrm{SO} 42-\mathrm{g} / \mathrm{L}$ and $\mathrm{pH}$ changes in two biotrickling filters. (a) Biotrickling filter 1, and (b) Biotrickling filter 2. 


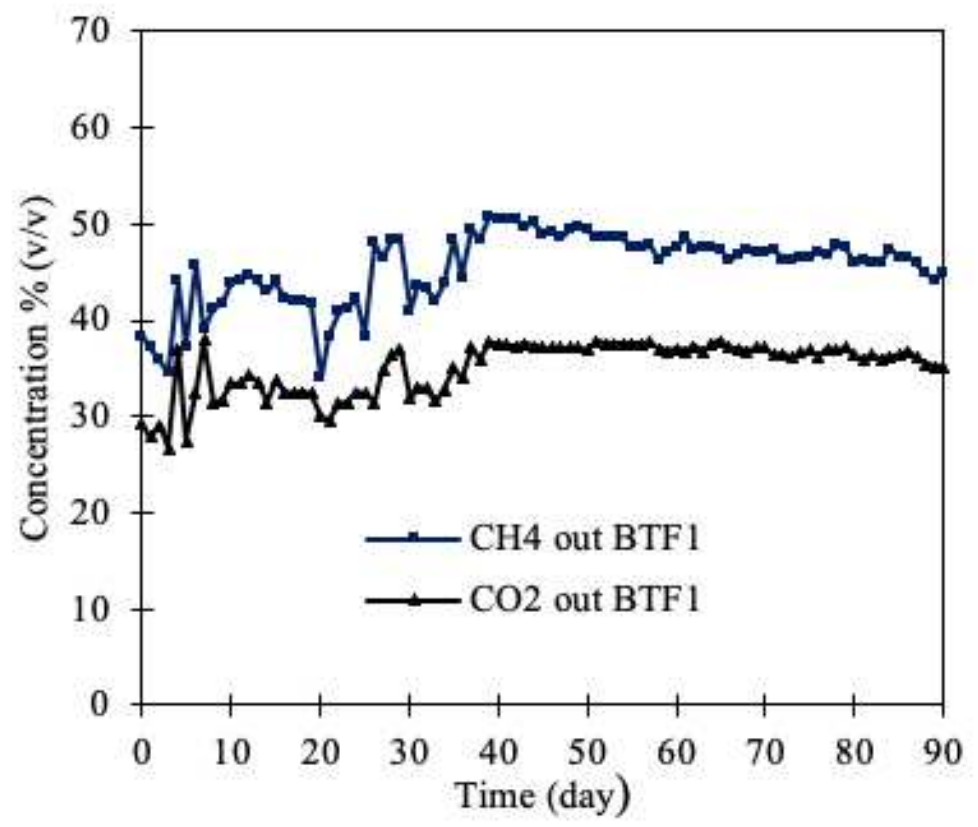

(a)

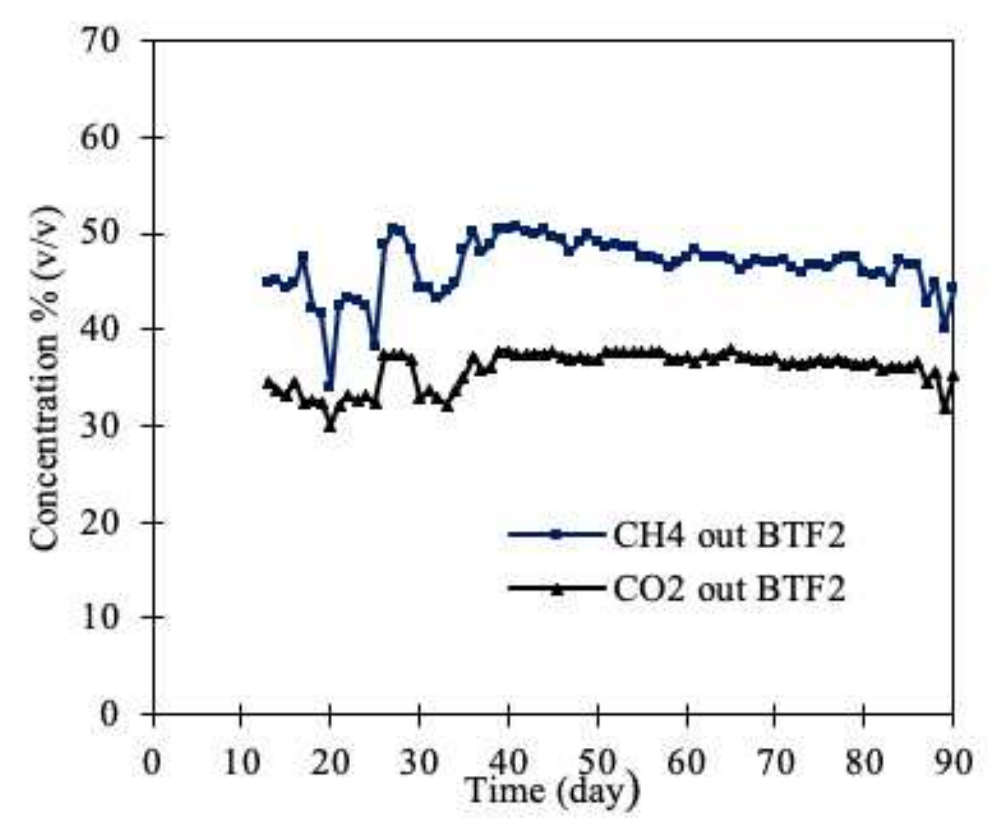

(b)

Figure 9

Methane and carbon dioxide composition in \% (v/v). (a) Biotrickling filter 1, and (b) Biotrickling filter 2. 


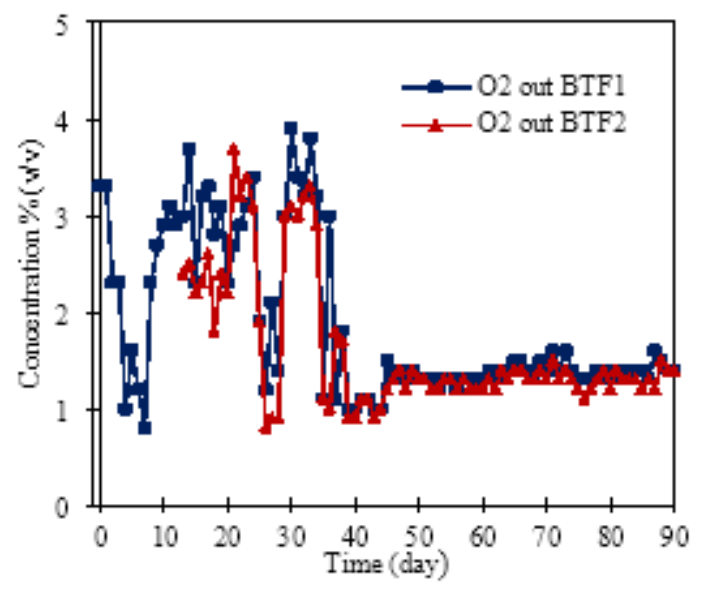

Figure 10

Oxygen concentration during operation of two biotrickling filters.

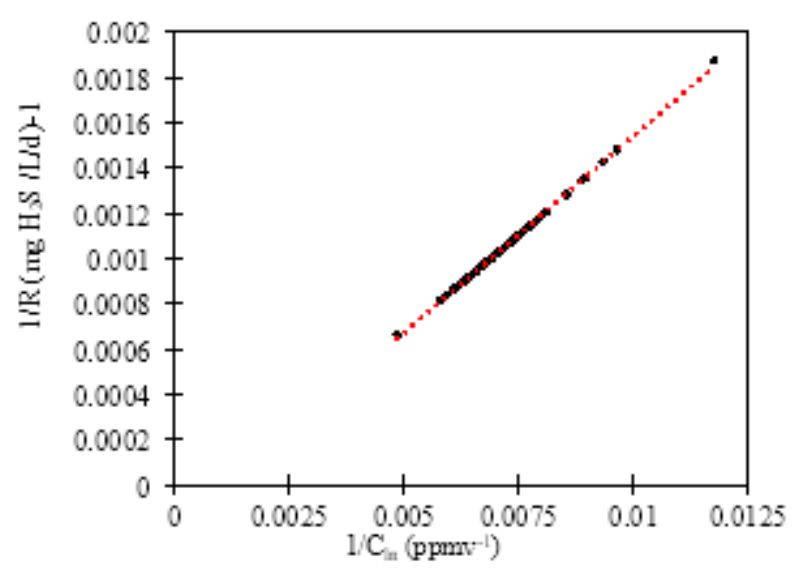

Figure 11

The linear relationship between $1 / \mathrm{R}$ and ${ }^{1} / \mathrm{C} \_$In for $\mathrm{H} 2 \mathrm{~S}$ degradation in the pilot scale biotrickling 